\title{
Role of the Kerguelen Plume in generating the eastern Indian Ocean seafloor
}

\author{
Dominique Weis \\ Département des Sciences de la Terre et de l'Environnement, Université Libre de Bruxelles \\ Brussels, Belgium
}

Frederick A. Frey

Department of Earth, Atmospheric and Planetary Sciences

Massachusetts Institute of Technology, Cambridge

\begin{abstract}
Mid-ocean ridge basalts (MORB) in the Indian Ocean have $\mathrm{Sr}-\mathrm{Nd}-\mathrm{Pb}$ isotopic characteristics that distinguish them from seafloor basalts in the Atlantic and Pacific Oceans. These differences have important implications for mantle dynamics. We discuss the isotopic variation with eruption age of seafloor basalts recovered by deep sea drilling at 10 sites in the eastern Indian Ocean ranging in age from Eocene to Late Jurassic. Except for alkalic basalts recovered from near Christmas Island in the northeast Indian Ocean, the basement lavas are tholeiitic basalts that are characterized by a wide range in incompatible element abundance ratios, such as $\mathrm{La} / \mathrm{Yb}$ and $\mathrm{Zr} / \mathrm{Nb}$. Most of the tholeiitic basalts from seven sites are geochemically similar to recent Indian Ocean MORB, but the alkalic basalts and tholeiitic lavas from two other sites have isotopic and incompatible element abundance ratios similar to lavas associated with the Kerguelen Plume. Two of these three sites, however, are not close to the track of this plume. The Dupal isotopic signature (relatively high ${ }^{87} \mathrm{Sr} /{ }^{86} \mathrm{Sr}$ and high $208 \mathrm{~Pb} / 204 \mathrm{~Pb}$ at a given ${ }^{206} \mathrm{~Pb} / 204 \mathrm{~Pb}$ ) is characteristic of lavas that have been attributed to the Kerguelen Plume, i.e., the Kerguelen Archipelago, Ninetyeast Ridge, and Kerguelen Plateau. Among eastern Indian Ocean seafloor basalts, a Dupal component is apparent in basement lavas from six of the seven drill sites in the eastern Indian Ocean that range in inferred age from $\sim 57$ to $125 \mathrm{Ma}$. The oldest $(-155 \mathrm{Ma})$ seafloor lavas recovered from the Indian Ocean, derived from a spreading center in the Argo Abyssal Plain near northwest Australia, have high $143 \mathrm{Nd} /{ }^{144} \mathrm{Nd}$ and low ${ }^{87} \mathrm{Sr} /{ }^{86} \mathrm{Sr}$ similar to the most depleted recent Indian MORB. Because the oldest volcanism on the Kerguelen Plateau $(\sim 118 \mathrm{Ma})$ is the first evidence of the activity of the Kerguelen Plume, this plume is inferred to be the source of Dupal isotopic characteristics in Indian Ocean MORBs. Some recent Indian Ocean MORB are also distinctive because many have relatively low ${ }^{206} \mathrm{~Pb} /{ }^{204} \mathrm{~Pb}(<17.4)$. Some of the oldest (110 to $155 \mathrm{Ma}$ ) seafloor lavas in the eastern Indian Ocean also have relatively low ${ }^{206} \mathrm{~Pb} / 204 \mathrm{~Pb}$ ratios. This low ${ }^{206} \mathrm{~Pb} / 204 \mathrm{~Pb}$ signature predates volcanism associated with the Kerguelen Plume and may reflect a significant role for continental lithosphere as a long-term source component for Indian Ocean MORB.
\end{abstract}

\section{Introduction}

Basalts erupted from active spreading ridge axes in the Indian Ocean define fields in $\mathrm{Sr}-\mathrm{Pb}, \mathrm{Nd}-\mathrm{Pb}$, and $\mathrm{Pb}-\mathrm{Pb}$ isotopic space that are distinct from the fields of mid-ocean ridge basalts (MORB) erupted in the Atlantic and Pacific Oceans [e.g., Subbarao and Hedge, 1973; Dupré and Allègre, 1983; Hamelin et al., 1985/1986; Michard et al., 1986; Price et al., 1986; Ito et al., 1987; Dosso et al., 1988; Mahoney et al., 1992]. These differences require that the basaltic Indian Ocean crust is derived from mantle sources that are unlike the sources of Atlantic and Pacific MORB. Hart [1988] proposed that oceanic island basalts (OIB) in the Indian Ocean are an important part of a large distinctive mantle isotopic domain (Dupal anomaly) that is

Copyright 1996 by the American Geophysical Union.

Paper number 96JB00410.

0148-0227/96/96JB-00410\$09.00 centered at $-30^{\circ} \mathrm{S}$ and is defined by ${ }^{87} \mathrm{Sr} /{ }^{86} \mathrm{Sr}>0.705$ and relatively high ${ }^{208} \mathrm{~Pb} /{ }^{204} \mathrm{~Pb}$ at a given ${ }^{206} \mathrm{~Pb} /{ }^{204} \mathrm{~Pb}$. The distinctive isotopic characteristics of Indian Ocean MORB have been attributed to the influence of Dupal components from the Kerguelen Plume [Hamelin et al., 1985/1986; Dosso et al., 1988; Storey et al., 1989], perhaps with contributions from the Crozet and Marion plumes [Mahoney et al., 1992]. An alternative explanation for the distinctive isotopic characteristics of Indian Ocean MORB, which is not mutually exclusive [Weis, 1992], is that ancient Gondwanaland continental lithosphere was dispersed and incorporated into the Indian Ocean MORB source during the breakup of Gondwanaland [Mahoney et al., 1989, 1992].

The geochemical characteristics of Indian Ocean seafloor as a function of eruption age are important in evaluating alternative interpretations for the distinctive geochemical features of recent Indian Ocean MORB. The Deep Sea Drilling Project (DSDP) and Ocean Drilling Program (ODP) recovered basalts of variable age, up to $155 \mathrm{Ma}$, from several sites within the eastern Indian Ocean. We studied these basalts in order to assess the relative roles of components derived from depleted mantle, mantle 
plumes, and continental lithosphere in the sources of basalt at each DSDP site and to determine how the proportions of these components changed with eruption age. In this paper we focus on 10 sites that are not on the Ninetyeast Ridge; Frey and Weis [1995] focus on the Ninetyeast Ridge.

\section{Research Approach}

Excluding the Ninetyeast Ridge, the eastern Indian Ocean was sampled at nine DSDP sites and one ODP site (Figure 1). Petrographic and geochemical characteristics of basalts from these DSDP sites were reported in the initial reports for DSDP Legs 22, 26, and 27 [von der Borch et al., 1974; Davies et al., 1974; Veevers et al., 1974], and a summary was given by Frey et al. [1977]. However, these previous studies did not include isotopic data for $\mathrm{Sr}, \mathrm{Nd}$, and $\mathrm{Pb}$ or precise abundance data for the incompatible trace elements, $\mathrm{Rb}, \mathrm{Ba}, \mathrm{Nb}, \mathrm{Sr}, \mathrm{Zr}, \mathrm{Hf}$, and $\mathrm{Y}$. This paper focuses on the isotopic ratios and abundance ratios of highly incompatible elements of eastern Indian Ocean seafloor basalts because these ratios are sensitive measures of geochemical heterogeneity in the oceanic mantle; e.g., they distinguish MORB from OIB [e.g., Weaver, 1991; Hart et al., 1992]. Old ocean floor rocks have been affected by postmagmatic alteration; thus abundance data for $\mathrm{Y}, \mathrm{Zr}, \mathrm{Nb}$, and rare earth elements (REE) are important because these elements are relatively immobile during postmagmatic alteration on the seafloor [Bienvenu et al., 1990]. In our discussion, we use "depleted" to refer to basalts that have $\mathrm{Rb} / \mathrm{Sr}, \mathrm{Nb} / \mathrm{Zr}, \mathrm{La} / \mathrm{Yb}, \mathrm{Ce} / \mathrm{Y}$ and $\mathrm{Nd} / \mathrm{Sm}$ ratios less than the estimated bulk earth ratios [e.g., Sun and McDonough, 1989]; that is, these basalts (and their mantle sources) are relatively depleted in the highly incompatible elements, $\mathrm{Rb}, \mathrm{Nb}, \mathrm{La}, \mathrm{Ce}$, and $\mathrm{Nd}$. With time these depleted sources develop ${ }^{143} \mathrm{Nd} / 144 \mathrm{Nd}$ greater than the bulk earth estimate and ${ }^{87} \mathrm{Sr} /{ }^{86} \mathrm{Sr}$ less than the bulk earth estimate. Conversely, relative to bulk earth, enriched basalts have higher $\mathrm{Rb} / \mathrm{Sr}, \mathrm{Nb} / \mathrm{Zr}, \mathrm{La} / \mathrm{Yb}, \mathrm{Ce} / \mathrm{Y}, \mathrm{Nd} / \mathrm{Sm}$, and ${ }^{87} \mathrm{Sr} /{ }^{86} \mathrm{Sr}$ but lower ${ }^{143} \mathrm{Nd} /{ }^{144} \mathrm{Nd}$.

\section{Analytical Techniques}

A subset of previously analyzed samples was selected to encompass the major element compositional range of these ocean floor lavas [Frey et al., 1977]. Trace element abundances were determined by $X$ ray fluorescence and instrumental neutron activation analysis (Table 1). Analytical procedures, and evaluation of data accuracy and precision are given by Frey et al. [1991]. Trace element analyses were done on unleached powders, but for isotopic analysis, the samples were leached in acid to remove secondary alteration phases. We used a leaching

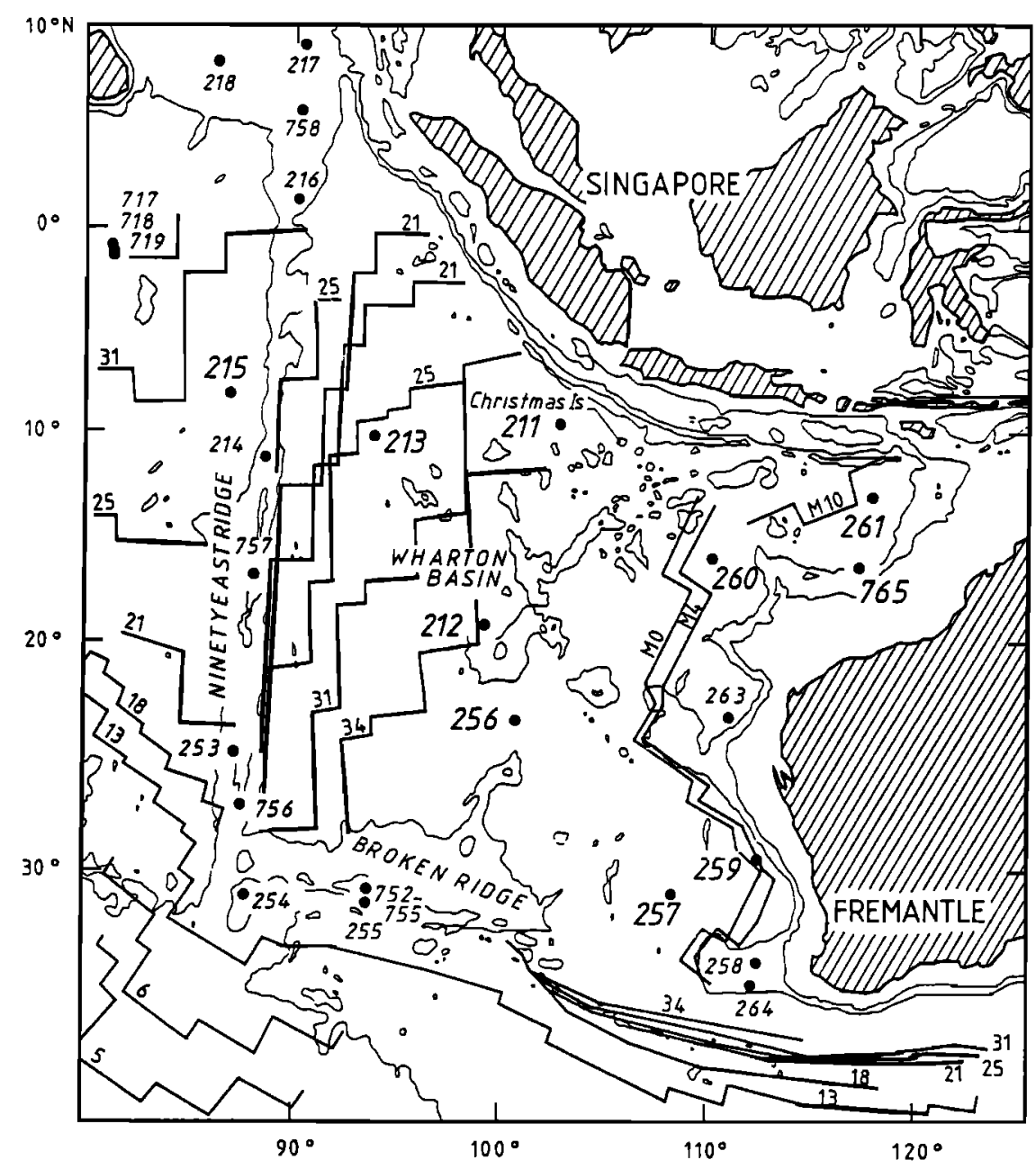

Figure 1. Location map for the eastern Indian Ocean showing selected magnetic anomalies, and major bathymetric features such as the Ninetyeast and Broken Ridges. DSDP and ODP drill sites are indicated as solid circles. The 10 seafloor sites discussed in this paper are shown by larger numbers. 
procedure comparable to Mahoney's [1987], i.e., "cold" acid leaching $(\mathrm{HCl} 6 \mathrm{~N})$, with elimination of the fines by removing the acid immediately after $\mathbf{3 0} \mathrm{min}$ in an ultrasonic bath (the time period of $\mathbf{3 0 ~} \mathrm{min}$ is critical as it allows for a slight increase in temperature, which is necessary to strengthen the leaching effect). This leaching procedure was repeated until a colorless solution was obtained [Weis and Frey, 1991], up to 10 steps for the most altered samples. After acid leaching, the remaining powder was rinsed with quartz-distilled water at least three times. The powder was dried on a hot plate until a constant weight was achieved. The difference between this final weight and the starting weight is the weight percent loss caused by acid leaching; typically, this was between 50 and $60 \%$. The large weight loss reflects dissolution of minerals formed during low-temperature alteration.

The samples were processed following standard chemical separation procedures (i.e., $\mathrm{HF}-\mathrm{HClO}_{4}$ dissolution and anion exchange column separation of the different isotopes following the method described by Weis et al. [1987]). The blanks for the columns were below $3 \mathrm{ng} \mathrm{Sr}$, and the total blanks for the whole procedure were below $6 \mathrm{ng}$ for $\mathrm{Sr}$ and below $2 \mathrm{ng}$ for $\mathrm{Nd}$. These blanks are negligible relative to the concentrations in the samples. For $\mathrm{Pb}$ isotopes, the samples were processed in a clean, over pressurized $(>3 \mathrm{~mm} \mathrm{Hg}$ ) laboratory, using reagents purified in a subboiling still. $\mathrm{Pb}$ was separated on anion exchange columns in a $\mathrm{HBr}-\mathrm{HCl}$ medium, following a method derived from Manhes $e t$ al. [1978]. $\mathrm{Pb}$ and $\mathrm{U}$ concentrations were measured on the same sample solution (aliquots were split before loading on columns and spiked with a ${ }^{235} \mathrm{U}_{-}{ }^{206} \mathrm{~Pb}$ mixed spike). $\mathrm{U}$ was separated in a $\mathrm{HNO}_{3}$ medium. Total blank values for $\mathrm{Pb}$ for the whole chemical procedure were typically below $1 \mathrm{ng}$.

Sr isotopic compositions were measured on single Ta filaments in the dynamic mode on a VG Sector 54 mass spectrometer. The internal precision for measured ${ }^{87} \mathrm{Sr} /{ }^{86} \mathrm{Sr}$ is better than $1 \times 10^{-5}$. The measured values are normalized to ${ }^{86} \mathrm{Sr} /{ }^{88} \mathrm{Sr}=0.1194$. For each barrel of 20 filaments, four analyses of NBS 987 Sr standard were made. The average of ${ }^{87} \mathrm{Sr} / 86 \mathrm{Sr}$ over the time period the DSDP analyses were made is $0.710232 \pm 8\left(2 \sigma_{m}\right.$ for 18$)$. An evaluation of between-run precision is also given by the replicate analyses reported in Table 2 . Nd isotopic compositions were measured on triple Ta-Re filaments with the VG Sector 54 multicollector mass spectrometer (analyses of the Merck Nd standard yielded ${ }^{143} \mathrm{Nd} /{ }^{144} \mathrm{Nd}=0.51173 \pm 1$ and ${ }^{145} \mathrm{Nd} /{ }^{144} \mathrm{Nd}$ $=0.348417 \pm 5\left(2 \sigma_{\mathrm{m}}\right.$ for 12$\left.)\right)$. Nd was run as a metal, and for each run the 146,145,144, and 143 isotopes were measured with all values normalized to ${ }^{146} \mathrm{Nd} /{ }^{144} \mathrm{Nd}=0.7219$.

$\mathrm{Pb}$ isotopic compositions and $\mathrm{Pb}$ and $\mathrm{U}$ concentrations by the isotope dilution (ID) technique were measured on single Re filaments with a Finnigan MAT 260 mass spectrometer, using the $\mathrm{H}_{3} \mathrm{PO}_{4}$-silica gel technique [e.g., Cameron et al., 1969]. All the results were corrected for mass fractionation $(0.13 \% \pm 0.04 \%$ per amu) on the basis of 72 analyses of the NBS $981 \mathrm{~Pb}$ standard [Catanzaro et al., 1968] for a temperature range of $1090^{\circ}$ to $1200^{\circ} \mathrm{C}$. Between-run precisions are better than $\approx 0.1 \%$ for ${ }^{206} \mathrm{~Pb} /{ }^{204} \mathrm{~Pb}$ and ${ }^{207} \mathrm{~Pb} /{ }^{204} \mathrm{~Pb}$ and better than $\approx 0.15 \%$ for ${ }^{208} \mathrm{~Pb} /{ }^{204} \mathrm{~Pb}$. The $\mathrm{Pb}$ and $\mathrm{U}$ concentrations have better than $2 \%$ precision.

The evolution of isotopic ratios with time must be considered when comparing present-day radiogenic isotopic ratios in lavas of different ages. Mahoney and Spencer [1991] discussed this problem in regard to lavas from the Ontong Java plateau. They noted that the $\mathrm{Rb} / \mathrm{Sr}, \mathrm{Sm} / \mathrm{Nd}, \mathrm{U} / \mathrm{Pb}$, and $\mathrm{Th} / \mathrm{Pb}$ in tholeiitic basalts are relatively low so that over $100 \mathrm{Myr}$ there is relatively little change in ${ }^{87} \mathrm{Sr} /{ }^{86} \mathrm{Sr},{ }^{143} \mathrm{Nd} /{ }^{144} \mathrm{Nd},{ }^{206} \mathrm{~Pb} /{ }^{204} \mathrm{~Pb},{ }^{207} \mathrm{~Pb} /{ }^{204} \mathrm{~Pb}$, and ${ }^{208} \mathrm{~Pb} /{ }^{204} \mathrm{~Pb}$. For example, in $120 \mathrm{Myr}$ a ${ }^{238} \mathrm{U} /{ }^{204} \mathrm{~Pb}=20$ (a relatively high value for unaltered oceanic basalts [White, 1993]) creates a change in ${ }^{206} \mathrm{~Pb} /{ }^{204} \mathrm{~Pb}$ of only 0.38 . In addition, tholeiitic basalts are commonly interpreted to result from relatively high extents of melting. Assuming parent/daughter abundance ratios are not strongly affected by the partial melting process, the isotopic ratios in the sources and tholeiitic lavas evolve similarly with time. Therefore Mahoney and Spencer [1991] concluded that over $100 \mathrm{Myr}$, age corrections are relatively small, especially when compared to isotopic differences among OIB, MORB, and oceanic plateau basalts.

However, postmagmatic alteration processes increase the complexity of inferring magmatic isotope ratios of old altered seafloor lavas, because postmagmatic alteration may affect isotopic ratios and parent/daughter abundance ratios. Typically, the isotopic ratios of $\mathrm{Nd}$ and $\mathrm{Pb}$ in oceanic basalts are not significantly changed during postmagmatic alteration, but formation of secondary phases with relatively high ${ }^{87} \mathrm{Sr} /{ }^{86} \mathrm{Sr}$ is common [e.g., Mahoney, 1987; Weis and Frey, 1991; Mahoney and Spencer, 1991; Staudigel et al., 1995]. As discussed earlier, in an effort to remove such secondary phases, the sample powders were repeatedly acid-leached before determination of ${ }^{87} \mathrm{Sr} / 86 \mathrm{Sr}$. Although most of the samples define an inverse $143 \mathrm{Nd} / 144 \mathrm{Nd}$ ${ }^{87} \mathrm{Sr} /{ }^{86} \mathrm{Sr}$ trend similar to that of unaltered oceanic basalts (Figure 2), we cannot be certain that these procedures completely remove all effects of postmagmatic alteration.

In contrast to unaltered tholeiitic basalts, corrections for radiogenic growth after eruption may be relatively large in highly altered lavas. This is especially true for $\mathrm{Sr}$ and $\mathrm{Pb}$ isotopic ratios, because $\mathrm{Rb} / \mathrm{Sr}$ and $\mathrm{U} / \mathrm{Pb}$ ratios may be significantly changed during alteration [e.g., Staudigel et al., 1995]. If alteration occurred soon after eruption, then over $100 \mathrm{Myr}$, the measured $\mathrm{Sr}$ and $\mathrm{Pb}$ isotopic ratios may differ considerably from those of the unaltered lavas at the time of eruption. In contrast, neither $\mathrm{Sm} / \mathrm{Nd}$ nor ${ }^{143} \mathrm{Nd} /{ }^{144} \mathrm{Nd}$ in ocean floor basalts are usually significantly changed by postmagmatic alteration. In addition, the long half-life of ${ }^{147} \mathrm{Sm}$ and low $\mathrm{Sm} / \mathrm{Nd}$ lead to a relatively small age correction.

For each DSDP site studied, Figure 2a shows fields for the present-day ${ }^{87} \mathrm{Sr} /{ }^{86} \mathrm{Sr}$ and ${ }^{143} \mathrm{Nd} /{ }^{144} \mathrm{Nd}$ values measured on the acid-leached residues. It also shows the age-corrected values calculated with the unleached whole rock $\mathrm{Rb} / \mathrm{Sr}$ and $\mathrm{Sm} / \mathrm{Nd}$ and ages inferred from magnetic anomalies or the age of the sediments overlying basaltic basement (Table 2). These corrections are likely to be too large for the $\mathrm{Sr}$ isotopic ratios because the $\mathrm{Rb} / \mathrm{Sr}$ of the whole rock is probably larger than that of the acid-leached residue and the alteration processes did not occur instantaneously upon eruption. Moreover, there is an inherent uncertainty in calculating initial isotopic ratios because the age of the basalts is not precisely known. However, it is significant that except for one sample from Site 212 (high ${ }^{87} \mathrm{Sr} /{ }^{86} \mathrm{Sr}$ ), age-corrected data points for ${ }^{87} \mathrm{Sr} /{ }^{86} \mathrm{Sr}$ and ${ }^{143} \mathrm{Nd} /{ }^{144} \mathrm{Nd}$ in acid-leached residues define a general inverse trend that largely overlaps the trend for recent MORB and OIB from the Indian Ocean (Figure $2 b$ ).

Figure 3a shows the effects of age correction on ${ }^{206} \mathrm{~Pb} /{ }^{204} \mathrm{~Pb}$ and ${ }^{207} \mathrm{~Pb} /{ }^{204} \mathrm{~Pb}$ based on the inferred minimum age of the basalt and the ${ }^{238} \mathrm{U} /{ }^{204} \mathrm{~Pb}$ measured on the acid-leached residues (Table 2). Accurate ${ }^{232} \mathrm{Th}$ abundance data are not available (below INAA detection limit in MORB); thus no correction was made to ${ }^{208} \mathrm{~Pb} /{ }^{204} \mathrm{~Pb}$ ratios. The ${ }^{238} \mathrm{U} /{ }^{204} \mathrm{~Pb}$ ratios of Indian Ocean MORB are typically 5 to 10 [White, 1993], but in the acid- 


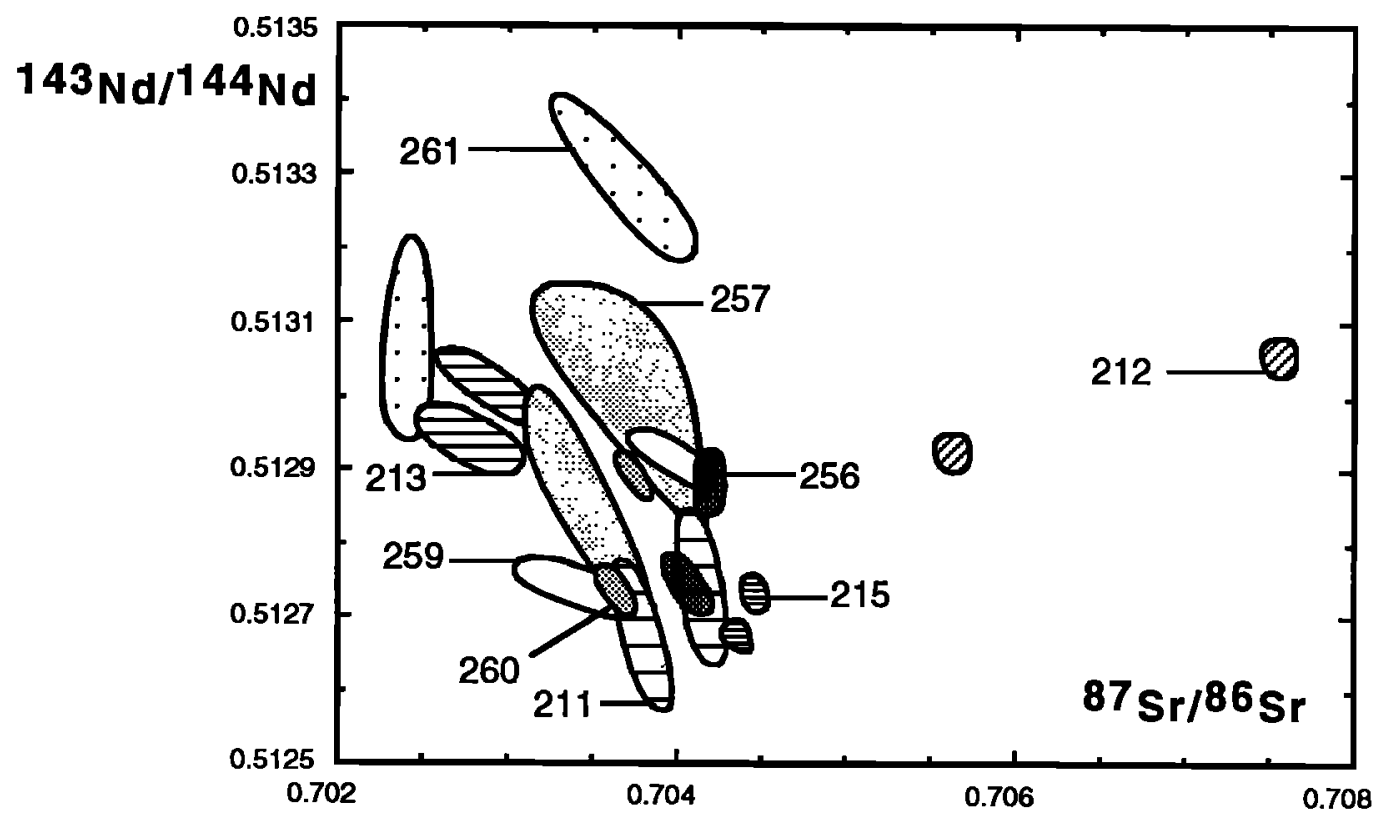

Figure 2a. The ratio of ${ }^{87} \mathrm{Sr} /{ }^{86} \mathrm{Sr}$ versus ${ }^{143} \mathrm{Nd} /{ }^{144} \mathrm{Nd}$ plot for basalts from the eastern Indian Ocean seafloor. For each site, the two fields indicate the effects of age corrections on ${ }^{87} \mathrm{Sr} /{ }^{86} \mathrm{Sr}$ and ${ }^{143} \mathrm{Nd} /{ }^{144} \mathrm{Nd}$ using measured $\mathrm{Rb} / \mathrm{Sr}$ and $\mathrm{Sm} / \mathrm{Nd}$ on unleached samples. Fields to the right are for acid-leached residues and fields to the left show age-corrected values. Ages (Table 2) were inferred from the age of the sediments overlying basaltic basement or nearby magnetic anomalies.

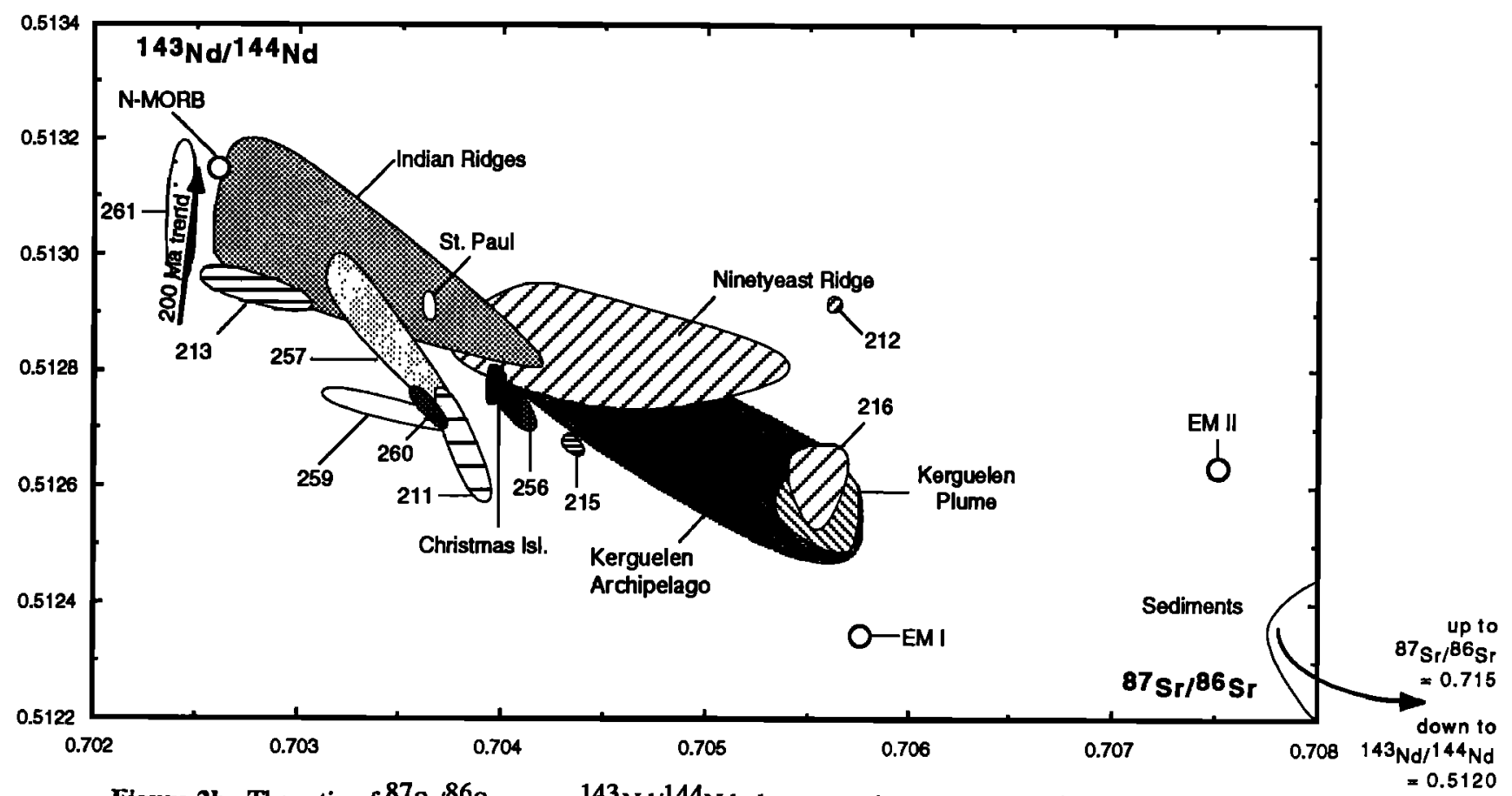

Figure 2b. The ratio of ${ }^{87} \mathrm{Sr} /{ }^{86} \mathrm{Sr}$ versus ${ }^{143} \mathrm{Nd} /{ }^{144} \mathrm{Nd}$ plot comparing age-corrected fields for old eastern Indian Ocean crust (this paper) to lavas from Ninetyeast Ridge drill sites with data for Site 216 shown as a distinct field [Mahoney et al., 1983; Hart, 1988; Saunders et al., 1991; Weis and Frey, 1991; Frey and Weis, 1995], fields for recent Indian Ocean MORB (see references in works by Weis et al. [1992] and Le Roex et al. [1983], Hamelin et al. [1985/86], Michard et al. [1986], Price et al. [1986], Dosso et al. [1988], and Mahoney et al. [1992]), the mantle components normal MORB (NMORB), enriched mantle 1 (EM1), and EM2 [Zindler and Hart, 1986] and fields for the Kerguelen Archipelago [Gautier et al., 1990; Weis et al., 1993a, b], Christmas [Hart, 1988; Falloon et al., 1989], and St. Paul Islands [Dosso et al., 1988]. The Kerguelen Plume composition is as defined by Weis et al. [1993a]. The Banda Sea sediment field is from Vroon et al. [1993]. Compared to the present-day fields for Indian Ridges and Kerguelen Archipelago, the fields of most DSDP sites (e.g., Site 259) are offset to lower ${ }^{143} \mathrm{Nd} /{ }^{144} \mathrm{Nd}$ at a given ${ }^{87} \mathrm{Sr} /{ }^{86} \mathrm{Sr}$. This offset reflects aging of the mantle source; e.g., the arrow labeled " $200 \mathrm{Ma}$ trend" shows aging of a MORB-like source for $200 \mathrm{Ma}$ (parent/daughter ratios for this source are averages for depleted MORB, $\mathrm{Rb} / \mathrm{Sr}=0.011$ and $\mathrm{Sm} / \mathrm{Nd}=0.336$ [Hofmann, 1988]; because of changes caused by melting these are maximum and minimum ratios, respectively. 


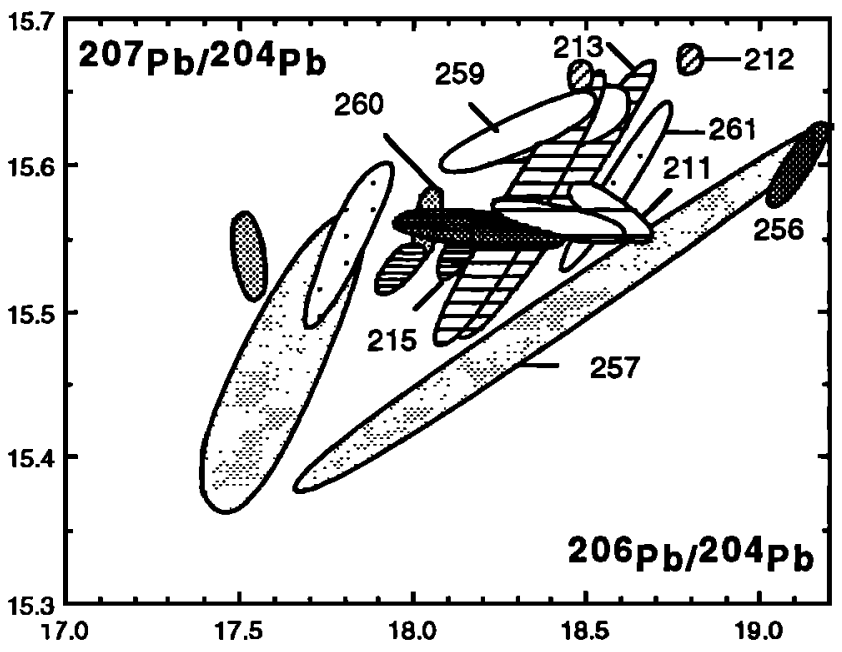

Figure 3a. The ratio ${ }^{207} \mathrm{~Pb} /{ }^{204} \mathrm{~Pb}$ versus ${ }^{206} \mathrm{~Pb} /{ }^{204} \mathrm{~Pb}$ plot for old eastern Indian Ocean basalts showing the effects of age corrections for in situ $U$ decay (measured fields on right and agecorrected fields on left; U/Pb measured on acid-leached residues). The age-corrections are especially large for Site 257 lavas, and the spread in ${ }^{206} \mathrm{~Pb} / 204 \mathrm{~Pb}$ is diminished by the age correction. Ages used for each site are given in Table 2. The true magmatic ratios are intermediate between the measured and age-corrected ratios (see discussion in text).

leached residues of these DSDP samples, ${ }^{238} \mathrm{U} /{ }^{204} \mathrm{~Pb}$ ranges from 4.8 to 163 and only 9 of 18 samples have ${ }^{238} \mathrm{U} /{ }^{204} \mathrm{~Pb}$ below 30. Consequently, in Figure $3 \mathrm{a}$ the ${ }^{206} \mathrm{~Pb} / 204 \mathrm{~Pb}$ age corrections for some samples are significant. As with the agecorrected ${ }^{87} \mathrm{Sr} /{ }^{86} \mathrm{Sr}$, we infer that the true magmatic ${ }^{206} \mathrm{~Pb} /{ }^{204} \mathrm{~Pb}$ ratios at the time of formation are intermediate between the measured and age-corrected ratios. An important result is that the age-corrected ${ }^{206} \mathrm{~Pb} /{ }^{204} \mathrm{~Pb}$ ratios for these DSDP basalts are within the range defined by young MORB and OIB from the Indian Ocean (Figures $3 c$ and 3d). Because of the low abundance of ${ }^{235} \mathrm{U}$ the age corrections for ${ }^{207} \mathrm{~Pb} /{ }^{204} \mathrm{~Pb}$ are less significant (Figure 3a).

\section{Results: General}

Although these basalts have been affected by postmagmatic alteration, major element analyses of the least altered lavas, and in some cases fresh glasses, show that the basalts are tholeiitic at eight of the nine DSDP sites studied [Frey et al., 1977]. Alkalic basalts containing titanaugite, amphibole, and small amounts of biotite and high abundances of relatively immobile incompatible elements (Figure 4) were recovered only at Site 211 [Frey et al., 1977]. Abundances of $\mathrm{Zr}$ and $\mathrm{Ce}$ are positively correlated with $\mathrm{Nb}$ abundance and reflect magmatic characteristics (Figure 4). Abundances of $\mathbf{R b}$ and $\mathrm{Ba}$ are not as well correlated with $\mathrm{Nb}$ abundance which probably reflects the effects of postmagmatic alteration; the scatter shows the difficulty in making a reliable age correction on the basis of measured $\mathrm{Rb} / \mathrm{Sr}$. The $\mathrm{Sr}, \mathrm{Nd}$, and $\mathrm{Pb}$ isotopic ratios in these DSDP basalts range widely, but they generally overlap with the range defined by Indian Ocean MORB, lavas from the Ninetyeast Ridge, and lavas from the Kerguelen Archipelago (Figures 2b, 3c and 3d). In the following section, we discuss each site proceeding from west to east across the eastern Indian Ocean.

\section{Results: Specific}

\section{Site $215\left(8^{\circ} 7.30^{\prime} \mathrm{S}, 8^{\circ} 47.50 ' \mathrm{E}\right)$}

This site was drilled $240 \mathrm{~km}$ west of the Ninetyeast Ridge and is off the ridge at $>5000 \mathrm{~m}$ water depth (Figure 1). Approximately $25 \mathrm{~m}$ of tholeiitic basalt, composed of at least 14 pillowed flows, were penetrated beneath $-59-60 \mathrm{Ma}$ sediments [Hekinian, 1974]. Unaltered glass is abundant in this core, and the high $\mathrm{K}_{2} \mathrm{O}(-1 \%)$ and $\mathrm{P}_{2} \mathrm{O}_{5}(\sim 0.25 \%)$ contents of these glasses indicate that these basalts are enriched in incompatible elements relative to depleted MORB [Melson et al., 1975; Frey et al., 1977]. These glasses (15 samples) are similar in composition, and our study of four additional whole rocks from different core sections confirms the geochemical homogeneity of lavas at this site (Table 1).

Site 215 basalts are more enriched in incompatible elements (i.e., higher $\mathrm{Ce} / \mathrm{Y}$ and $\mathrm{La} / \mathrm{Yb}$ and lower $\mathrm{Zr} / \mathrm{Nb}$ ) than basaltic lavas recovered from the Ninetyeast Ridge (Figure 5), a linear volcanic ridge (Figure 1) that is interpreted to be the trace of the Kerguelen Plume on the Indian Plate [e.g., Weis et al., 1992]. Relative to the transitional basalts of the Kerguelen Archipelago [Gautier et al., 1990], the Site 215 basalts have similar $\mathrm{Ce} / \mathrm{Y}$ but tend to lower $\mathrm{La} / \mathrm{Yb}$ and $\mathrm{Zr} / \mathrm{Nb}$ (Figure 5). In addition, Site 215 basalts have ${ }^{87} \mathrm{Sr} /{ }^{86} \mathrm{Sr},{ }^{143} \mathrm{Nd} /{ }^{144} \mathrm{Nd},{ }^{207} \mathrm{~Pb} /{ }^{204} \mathrm{~Pb}$ and ${ }^{208} \mathrm{~Pb} /{ }^{204} \mathrm{~Pb}$ similar to these transitional Kerguelen basalts (Figures $2 \mathrm{~b}, 3 \mathrm{c}$ and 3d). Although the calculated initial ${ }^{206} \mathrm{~Pb} /{ }^{204} \mathrm{~Pb}$ (17.94-17.99) are lower than in lavas from the Kerguelen Archipelago, the relatively low measured ${ }^{206} \mathrm{~Pb} /{ }^{204} \mathrm{~Pb}(18.10-18.15)$ overlap with those of the upper Miocene alkaline lavas of the southeast Kerguelen Archipelago, which have been interpreted by Weis et al. [1993a] to be representative of the Kerguelen Plume (Figures $3 c$ and 3d). Therefore basalts from Site 215 have the high $\Delta 7 / 4$ $(8-9)$ and $\Delta 8 / 4$ (81-85) that define the Dupal isotopic anomaly and characterize the Kerguelen Plume [e.g., Gautier et al., 1990; Weis et al., 1989a, b], where $\Delta 7 / 4=\left[\left({ }^{207} \mathrm{~Pb} /{ }^{204} \mathrm{~Pb}\right)_{\text {sample }}\right.$ $\left({ }^{207} \mathrm{~Pb} /{ }^{204} \mathrm{~Pb}\right)_{\mathrm{NHRL}} \mathrm{x} \times 100$, with the NHRL equation being $\left.{ }^{207} \mathrm{~Pb} /{ }^{204} \mathrm{~Pb}=0.1084\left({ }^{206} \mathrm{~Pb} /{ }^{204} \mathrm{~Pb}\right)+13.491\right)$ and $\Delta 8 / 4=$ $\left[\left({ }^{208} \mathrm{~Pb} /{ }^{204} \mathrm{~Pb}\right)_{\text {sample }}-\left({ }^{208} \mathrm{~Pb} /{ }^{204} \mathrm{~Pb}\right) \mathrm{NHRL}\right] \times 100$, with the

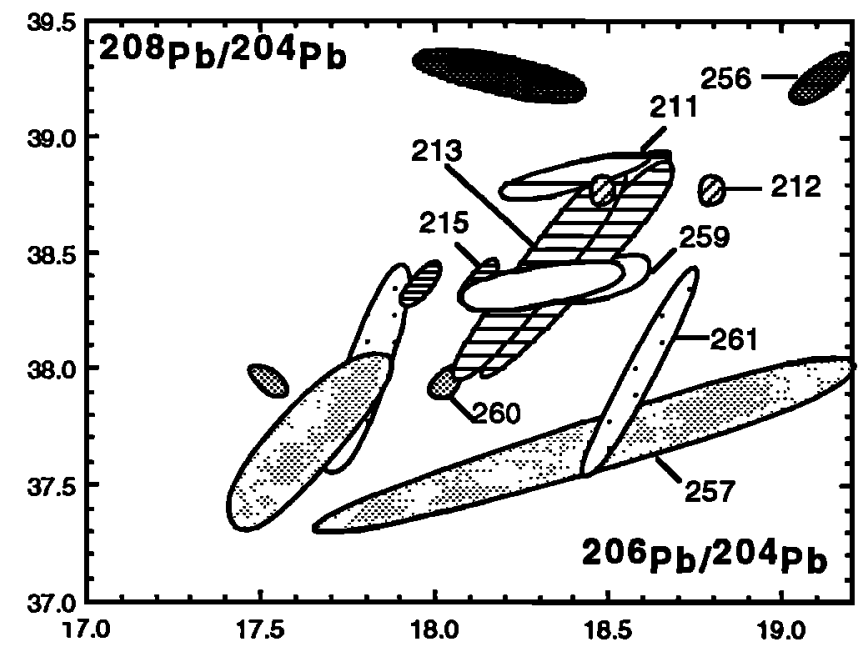

Figure 3b. The ratio ${ }^{208} \mathrm{~Pb} /{ }^{204} \mathrm{~Pb}$ versus ${ }^{206} \mathrm{~Pb} /{ }^{204} \mathrm{~Pb}$ plot showing effects of age corrections on ${ }^{206} \mathrm{~Pb} /{ }^{204} \mathrm{~Pb}$. (See Figure $3 \mathrm{a}$ caption.). No corrections are indicated for ${ }^{208} \mathrm{~Pb} / 204 \mathrm{~Pb}$ as no accurate ${ }^{232} \mathrm{Th}$ abundance data are available. 


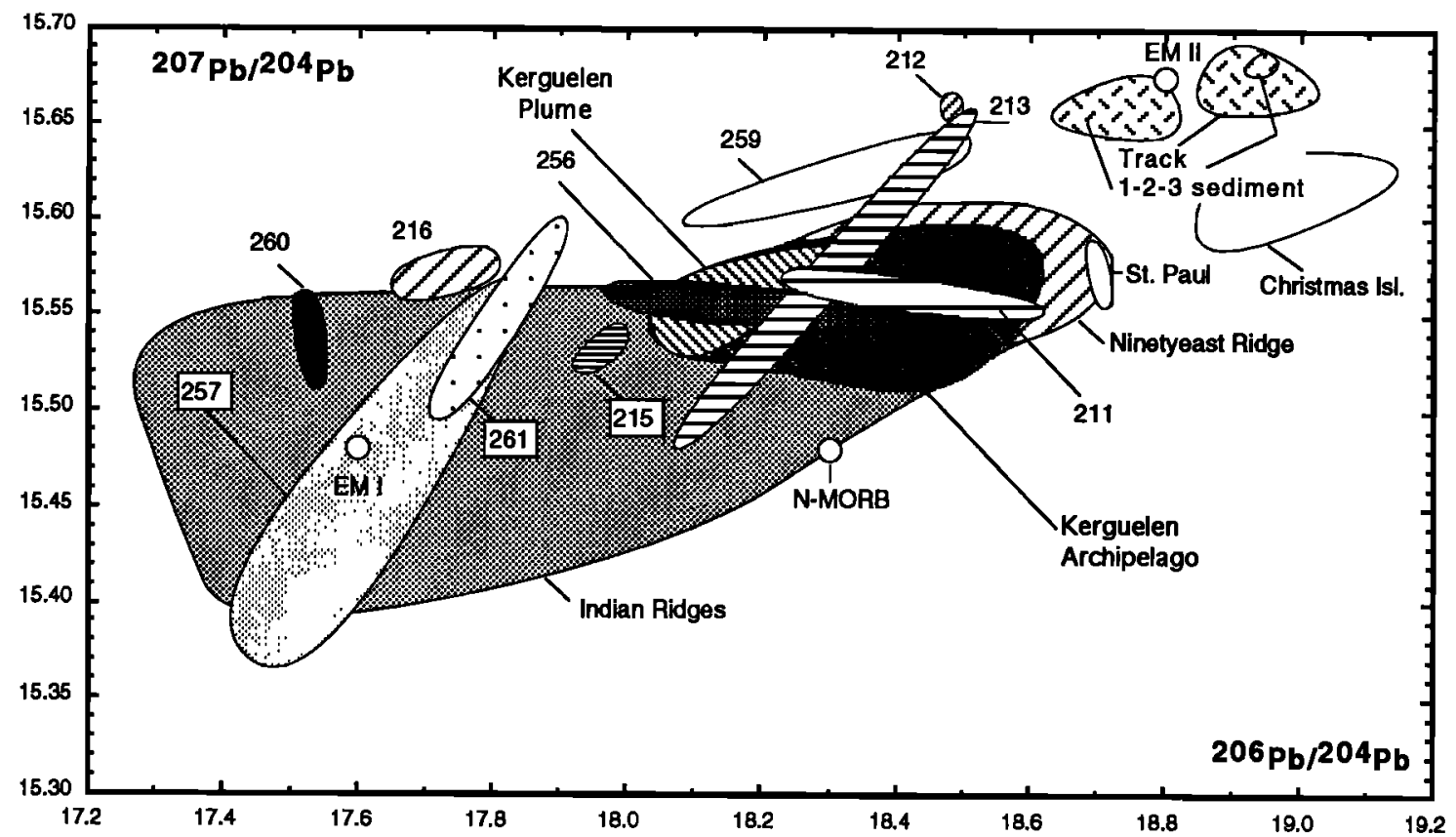

Figure 3c. The ratio ${ }^{207} \mathrm{~Pb} /{ }^{204} \mathrm{~Pb}$ versus ${ }^{206} \mathrm{~Pb} /{ }^{204} \mathrm{~Pb}$ plot comparing age-corrected fields for old Indian Ocean crust basalts (Figure 3a) to fields for the Ninetyeast Ridge (data for Site 216 are shown as a separate field), recent Indian Ocean MORB, mantle components, and the Kerguelen, Christmas and St. Paul Islands. Data sources are as given for Figure $2 \mathrm{~b}$. One sample of Site $260(20-1,16-18 \mathrm{~cm})$ has a ${ }^{206} \mathrm{~Pb} / 204 \mathrm{~Pb}>20$ and has not been plotted. Track 1-2-3 sediment fields are data for sediments collected from three transects in the Banda Sea [Vroon et al., 1993].

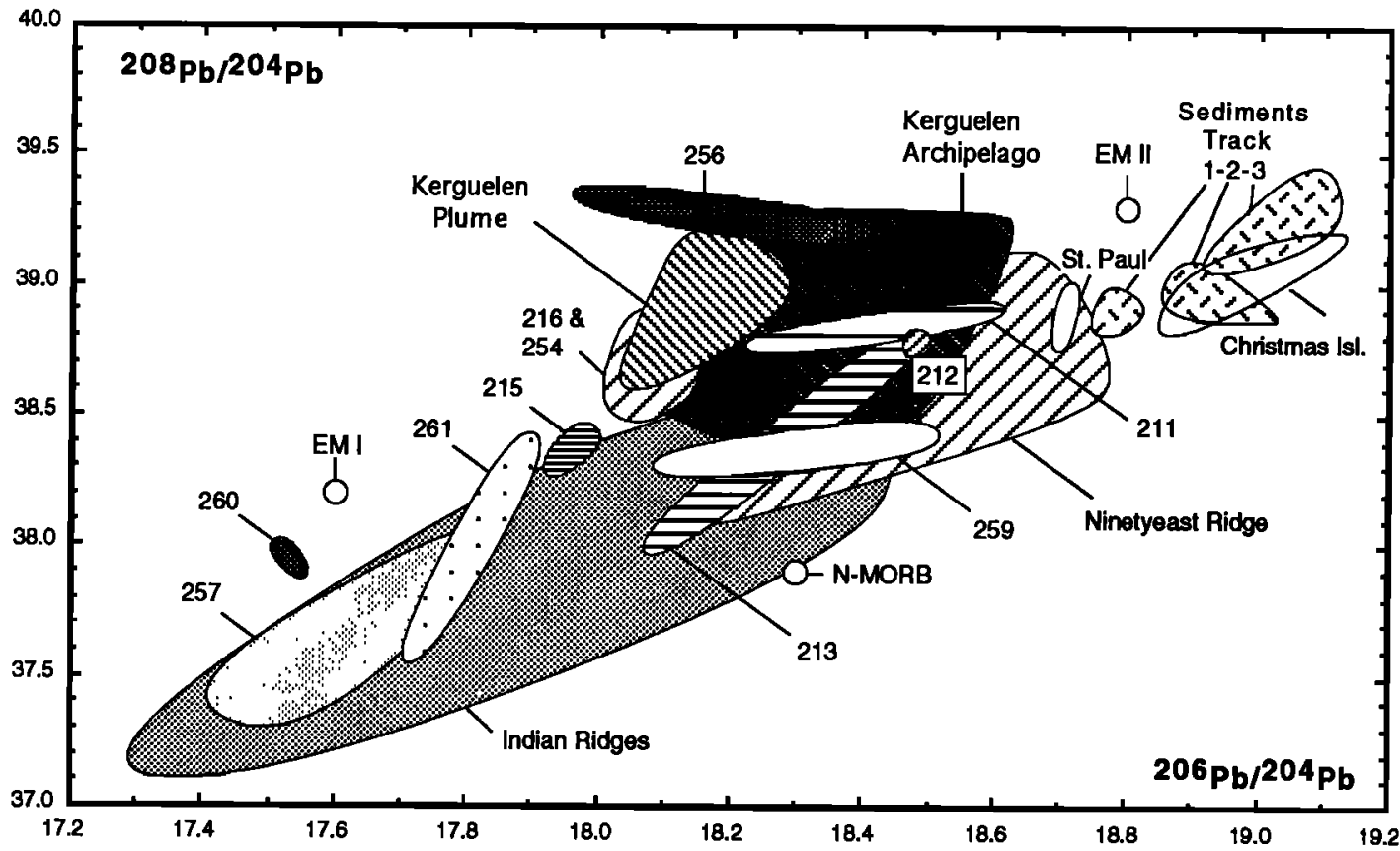

Figure 3d. The ratio ${ }^{208} \mathrm{~Pb} /{ }^{204} \mathrm{~Pb}$ versus ${ }^{206} \mathrm{~Pb} /{ }^{204} \mathrm{~Pb}$ plot (only ${ }^{206} \mathrm{~Pb} /{ }^{204} \mathrm{~Pb}$ data have been age corrected, see Figure 3b). Fields are as in Figure 3c, except that data for the two Ninetyeast Ridge sites (216 and 254) with relatively low ${ }^{206} \mathrm{~Pb} /{ }^{204} \mathrm{~Pb}$ are indicated. 

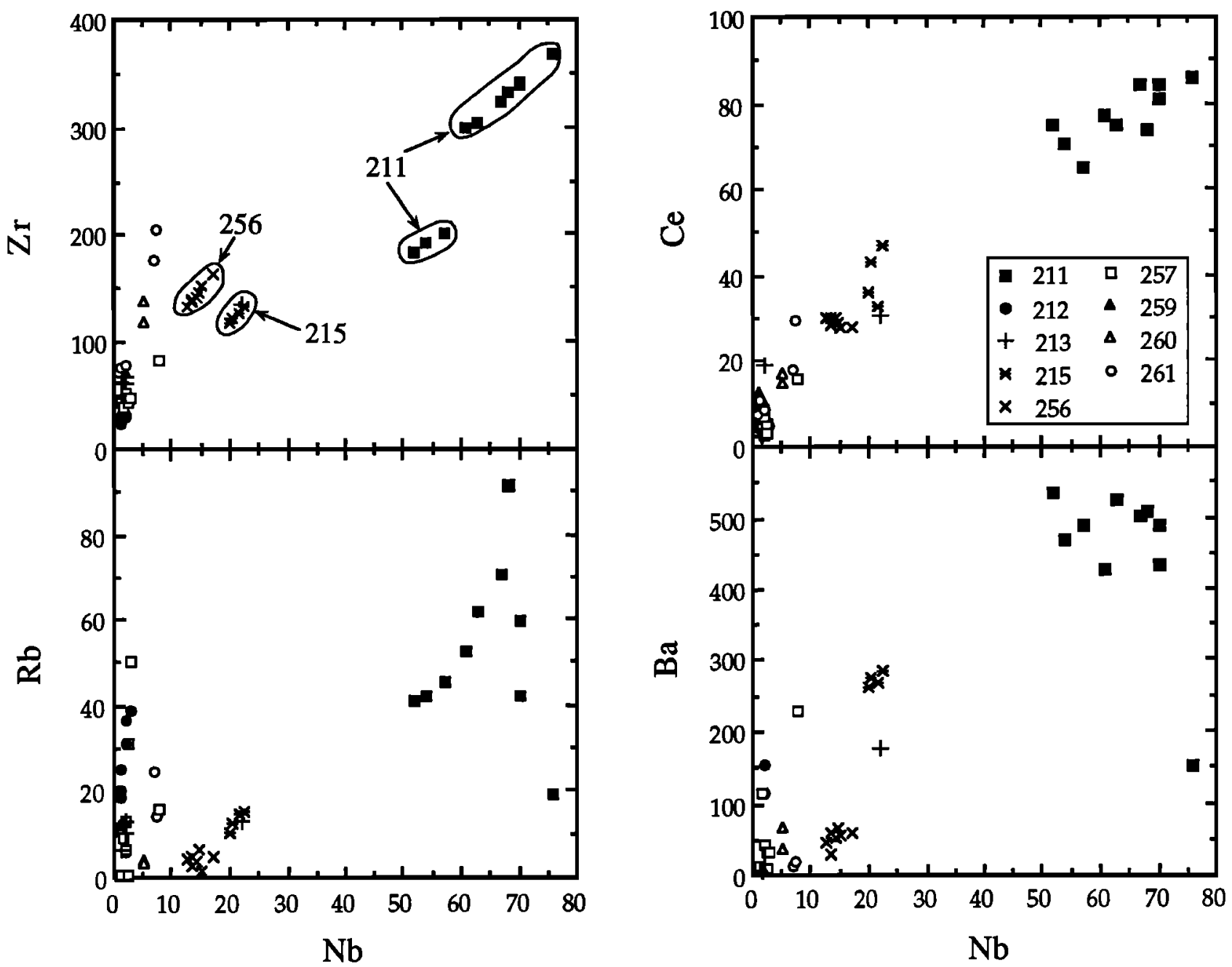

Figure 4. Abundance of various incompatible elements (in ppm) versus $\mathrm{Nb}$ content (in $\mathrm{ppm}$ ) in basalts from the eastern Indian Ocean seafloor. The highest abundances are in the alkalic basalts from Site 211. Except for Rb and $\mathrm{Ba}$, which have been affected by postmagmatic alteration, the abundances of incompatible elements are positively correlated.

NHRL equation being ${ }^{208} \mathrm{~Pb} /{ }^{204} \mathrm{~Pb}=1.209\left({ }^{206} \mathrm{~Pb} /{ }^{204} \mathrm{~Pb}\right)+$ 15.627 [Hart, 1984].

\section{Site $213\left(1^{\circ} 12.71 ' S, 93^{\circ} 53.77^{\prime} \mathrm{E}\right)$}

This site is in the western Wharton Basin $500 \mathrm{~km}$ east of the Ninetyeast Ridge and separated from the Ninetyeast Ridge by the Ninetyeast Fracture Zone. It is near the east-west trending Chron 25; if these basalts formed at a spreading ridge axis, they erupted at the east-west striking spreading center that became extinct in the middle Eocene (Figure 1). Eighteen meters of pillow basalt were recovered beneath $56-58 \mathrm{Ma}$ sediments. In contrast to Site 215 , glasses from this site have low $\mathrm{K}_{2} \mathrm{O}(0.06 \%)$ and $\mathrm{P}_{2} \mathrm{O}_{5}$ (0.09\%) contents [Melson et al., 1975]. Frey et al. [1977] concluded that Site 213 basalts are depleted MORB. Our study of five samples confirms that most of the basalts in this core are depleted MORB in composition (Figures 4 and 5) and in $\mathrm{Sr}$ and $\mathrm{Nd}$ isotopic ratios (Figure 2b). However, the lowermost basalt studied from this core is geochemically distinct. It is relatively enriched in the incompatible elements $\mathrm{Ba}, \mathrm{Nb}, \mathrm{Sr}, \mathrm{Zr}$, and light REE (Table 1 and Figure 4) and has higher ${ }^{87} \mathrm{Sr} / 86 \mathrm{Sr}$ and lower ${ }^{143} \mathrm{Nd} /{ }^{144} \mathrm{Nd}$ than the sample with lower incompatible element abundances. However, its $\mathrm{Sr}$ and Nd isotopic ratios are within the
Indian Ocean MORB field (Table 2 and Figure 2b). Compared to Indian Ocean MORB, this sample has anomalously high $\mathrm{Pb}$ isotopic ratios, e.g., ${ }^{207} \mathrm{~Pb} /{ }^{204} \mathrm{~Pb}=15.65$, which is also higher than those of lavas from the Kerguelen Archipelago (Table 2 and Figures $3 c$ and $3 d$ ).

\section{Site $212\left(1^{\circ} 11.34^{\prime} S, 9^{\circ} 17.84^{\prime} \mathrm{E}\right)$}

This site was drilled in the deepest part of the Wharton Basin $(6233 \mathrm{~m})$ at the southern end of a long linear topographic high, the Investigator Ridge, and near the east-west trending Chron 34 (Figure 1). The sediment overlying the basalt lacks fossils, and the age of the basement is poorly constrained to be $-100 \mathrm{Ma}$ [Sclater et al., 1974]; Powell et al. [1988] used magnetic anomalies to infer a basement age of $90 \mathrm{Ma}$. Five meters of pillow basalt were penetrated. These basalts are very altered, typically 5-10\% weight loss on ignition [Hekinian, 1974]. Analysis of a single glass chip and whole rocks shows that these basalts have very low $\mathrm{TiO}_{2}$ and $\mathrm{Zr}$ abundances [Melson et al., 1975; Frey et al., 1977]. Our data for six basalts show that they have very high $\mathrm{Cr}$ abundances ( $-800 \mathrm{ppm}$, Table 1$)$ which is consistent with the high $\mathrm{MgO}(9.0 \%)$ and $\mathrm{CaO}(13.5 \%)$ of the glass. The whole rocks also have low abundances of 
Table 1. Abundances of Trace Elements in DSDP Basalts From the Eastern Indian Ocean

\begin{tabular}{|c|c|c|c|c|c|c|}
\hline & \multicolumn{6}{|c|}{ Site 215} \\
\hline & $\begin{array}{l}18-2 \\
47-53 \\
\end{array}$ & \multicolumn{2}{|r|}{$\begin{array}{l}18-2 \\
106-110 \\
\end{array}$} & & $\begin{array}{l}18-3 \\
110-112 \\
\end{array}$ & $\begin{array}{l}19-2 \\
145-150\end{array}$ \\
\hline $\mathbf{R b}$ & \multicolumn{2}{|l|}{15.5} & \multicolumn{2}{|l|}{14.5} & 10.6 & 12.7 \\
\hline $\mathrm{Sr}$ & 284 & \multicolumn{2}{|r|}{284} & & 282 & 294 \\
\hline $\mathrm{Ba}$ & 285 & \multicolumn{2}{|r|}{269} & & 262 & 274 \\
\hline V & 213 & & 187 & & 174 & 192 \\
\hline $\mathrm{Cr}$ & 258 & & 237 & & 299 & 215 \\
\hline $\mathrm{Ni}$ & 105 & & 101 & & 100 & 92 \\
\hline $\mathrm{Zn}$ & 72 & & 64 & & 58 & 64 \\
\hline $\mathrm{Ga}$ & 17.2 & & 18.4 & & 17.6 & 17.7 \\
\hline $\mathbf{Y}$ & 27.4 & & 26.6 & & 27.0 & 27.3 \\
\hline $\mathbf{Z r}$ & 134 & & 127 & & 118 & 122 \\
\hline $\mathrm{Nb}$ & 22.5 & & 21.6 & & 20.2 & 20.6 \\
\hline Hf & & & 2.82 & & 3.1 & - \\
\hline $\mathbf{L a}$ & & & 14.5 & & 16.2 & \\
\hline $\mathrm{Ce}$ & 47 & & 32.6 & & 36 & 43 \\
\hline $\mathrm{Nd}$ & & & 16.8 & & 20.1 & \\
\hline Sm & & & 4.17 & & 4.5 & \\
\hline $\mathrm{Eu}$ & & & 1.41 & & 1.5 & \\
\hline $\mathrm{Tb}$ & & & 0.75 & & 0.8 & \\
\hline $\mathbf{Y b}$ & & & 2.56 & & 2.5 & \\
\hline Lu & & & 0.37 & & 0.51 & \\
\hline & & & & Site 213 & & \\
\hline & $\begin{array}{l}17-2 \\
108-110\end{array}$ & $\begin{array}{l}17-3 \\
90-99\end{array}$ & & $\begin{array}{l}18-2 \\
115-117\end{array}$ & $\begin{array}{l}19-2 \\
54-56\end{array}$ & $\begin{array}{l}19-2 \\
127-130\end{array}$ \\
\hline $\mathbf{R b}$ & 12.3 & 10.5 & & 6.5 & 13.3 & 13.3 \\
\hline $\mathbf{S r}$ & 127 & 136 & & 121 & 122 & 260 \\
\hline $\mathbf{B a}$ & 7 & 15 & & & 14 & 176 \\
\hline V & 230 & 256 & & 236 & 248 & 219 \\
\hline $\mathrm{Cr}$ & 327 & 319 & & 330 & 354 & 225 \\
\hline $\mathrm{Ni}$ & 90 & 104 & & 82 & 101 & 71 \\
\hline $\mathrm{Zn}$ & 106 & 84 & & 151 & 132 & 146 \\
\hline $\mathrm{Ga}$ & 15.8 & 17.0 & & 16.2 & 16.5 & 18.6 \\
\hline $\mathbf{Y}$ & 22.5 & 26.7 & & 23.6 & 26.7 & 29.0 \\
\hline $\mathbf{Z r}$ & 61 & 62 & & 64 & 68 & 135 \\
\hline Nb & 1.6 & 2.0 & & 1.1 & 2.1 & 22 \\
\hline Hf & & & & & & 3.2 \\
\hline $\mathbf{L a}$ & & & & 2.2 & & 18.8 \\
\hline $\mathrm{Ce}$ & 3 & 19 & & 7.6 & 6.3 & 30.8 \\
\hline Nd & & & & 6.2 & & 16.4 \\
\hline $\mathrm{Sm}$ & & & & 2.18 & & 4.23 \\
\hline $\mathrm{Eu}$ & & & & 0.85 & & 1.65 \\
\hline $\mathrm{Tb}$ & & & & 0.64 & & 0.74 \\
\hline $\mathbf{Y b}$ & & & & 2.55 & & 2.75 \\
\hline $\mathrm{Lu}$ & & & & 0.41 & & 0.39 \\
\hline
\end{tabular}

incompatible elements such as $\mathrm{Y}, \mathrm{Zr}, \mathrm{Nb}$, and $\mathrm{REE}$; the erratic and high contents of $R b$ and $B a$ reflect the high extent of alteration (Table 1 and Figure 4). However, these low abundances are not accompanied by MORB-like $\mathrm{Zr} / \mathrm{Nb}, \mathrm{Ce} / \mathrm{Y}$, and $\mathrm{La} / \mathrm{Yb}$, which are more similar to the ratios in lavas from the Ninetyeast Ridge (Figure 5).

One sample from Site 212 was analyzed for its isotopic compositions. It has a ${ }^{143} \mathrm{Nd} /{ }^{144} \mathrm{Nd}$ typical of depleted MORB, but even the acid-leached residue has still a very high ${ }^{87} \mathrm{Sr} /{ }^{86} \mathrm{Sr}$ $(0.70755)$ that must reflect the extremely altered nature of these basalts [Hekinian, 1974]. Apparently, some of the postmagmatic phases were not removed by the acid leaching. With respect to
$\mathrm{Pb}$ isotopic ratios, this sample is similar to the lowermost basalt studied at Site 213; that is, it has $\mathrm{Pb}$ isotopic ratios higher than Indian Ocean MORB and its ${ }^{207} \mathrm{~Pb} /{ }^{204} \mathrm{~Pb}$ (15.66) is higher than lavas from the Kerguelen Archipelago, comparable to those of Indian Ocean sediments [Vroon et al., 1993]. Hence it has a high $\Delta 7 / 4$ of 14.4 , although its ${ }^{208} \mathrm{~Pb} / 204 \mathrm{~Pb}$ falls within the Kerguelen field (Figures $3 c$ and 3d).

\section{Slte $211\left(9^{\circ} 46.53 ' \mathrm{~S}, 102^{\circ} 41.95 ' \mathrm{E}\right)$}

This site was drilled in deep water (5525 m) west of Christmas Island. Christmas Island is composed of alkaline basalts ranging 
Table 1. (continued)

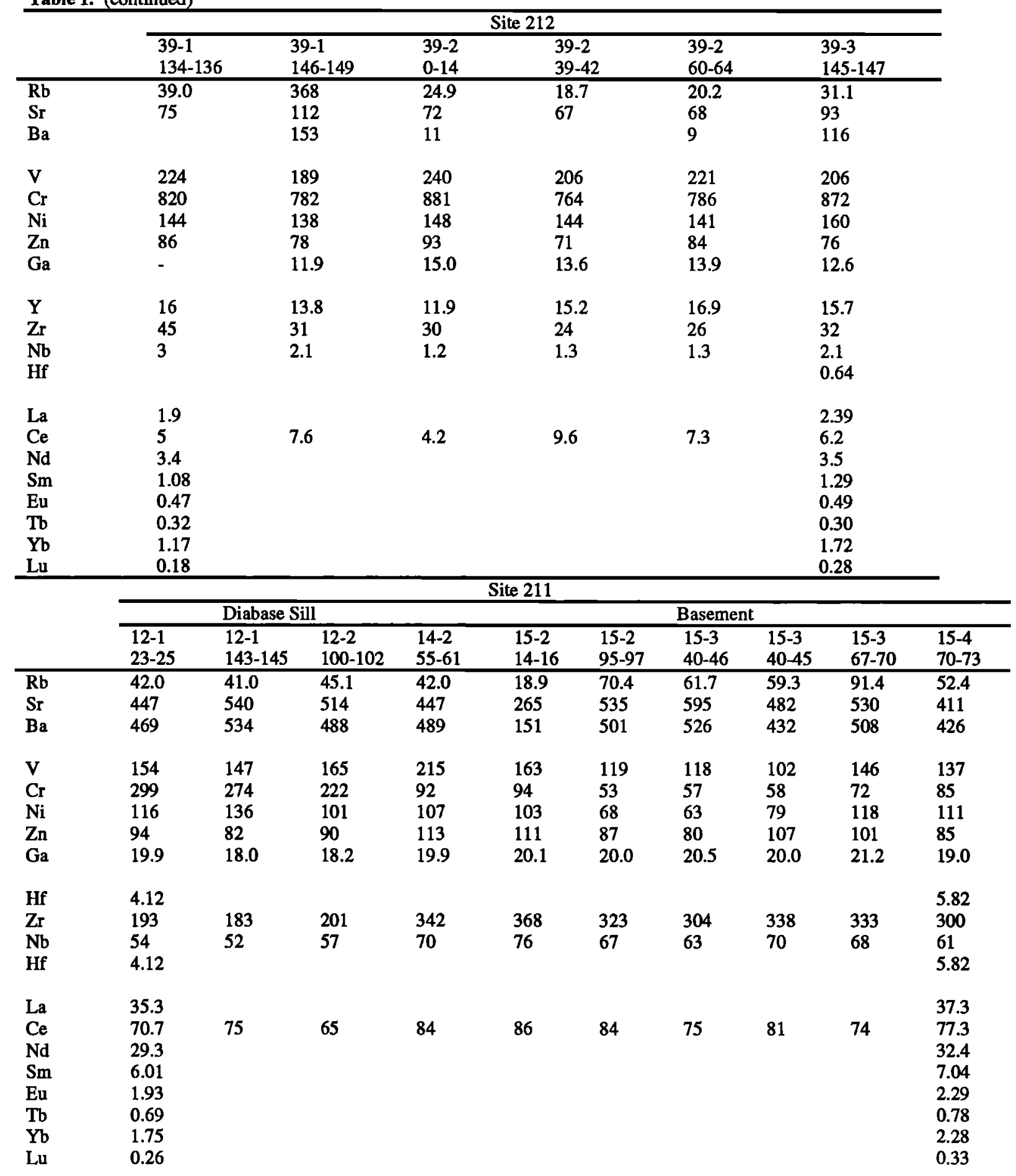

in age from Eocene to Miocene [Smith and Mountain, 1925; Falloon et al., 1989]. These basalts have relatively radiogenic $\mathrm{Pb}$ isotopic compositions with ${ }^{206} \mathrm{~Pb} /{ }^{204} \mathrm{~Pb}>18.8$ [Hart, 1988]. At Site 211 a $10-\mathrm{m}$-thick diabase sill $\left({ }^{40} \mathrm{Ar} / 39 \mathrm{Ar}\right.$ age of $71 \mathrm{Ma}$ [McDougall, 1974]) occurs $18 \mathrm{~m}$ above an amphibole-bearing basaltic basement that is inferred to be $>76 \mathrm{Ma}$. Although the sill has significantly lower abundances of $\mathrm{Nb}$ and $\mathrm{Zr}$ than the basement lavas (Table 1 and Figure 4), all of the lavas from this site are alkalic basalts that are very enriched in incompatible elements relative to the lavas from the other sites (Figure 4). In terms of $\mathrm{La} / \mathrm{Yb}, \mathrm{Ce} / \mathrm{Y}$ and $\mathrm{Zr} / \mathrm{Nb}$, Site 211 lavas are similar to the mildly alkaline suite of the Kerguelen Archipelago (Figure 5). These are the only alkalic lavas recovered from the eastern Indian Ocean seafloor.

The $\mathrm{Sr}$ and Nd isotopic ratios of a basement lava from Site 211 are close to those of Christmas Island lavas (Figure 2b). Compared to lavas from Christmas Island, this Site 211 basalt has lower ${ }^{206} \mathrm{~Pb} /{ }^{204} \mathrm{~Pb}$ and ${ }^{207} \mathrm{~Pb} /{ }^{204} \mathrm{~Pb}$ (Figures $3 \mathrm{c}$ and 3d), but its ${ }^{206} \mathrm{~Pb} /{ }^{204} \mathrm{~Pb}$ ratio is nevertheless the highest value measured on samples of the northeastern Indian Ocean seafloor (except for an anomalous sample from Site 260, Table 2). The $\mathrm{Pb}$ isotopic ratios of the sill sample overlap with the upper Miocene alkalic 
Table 1. (continued)

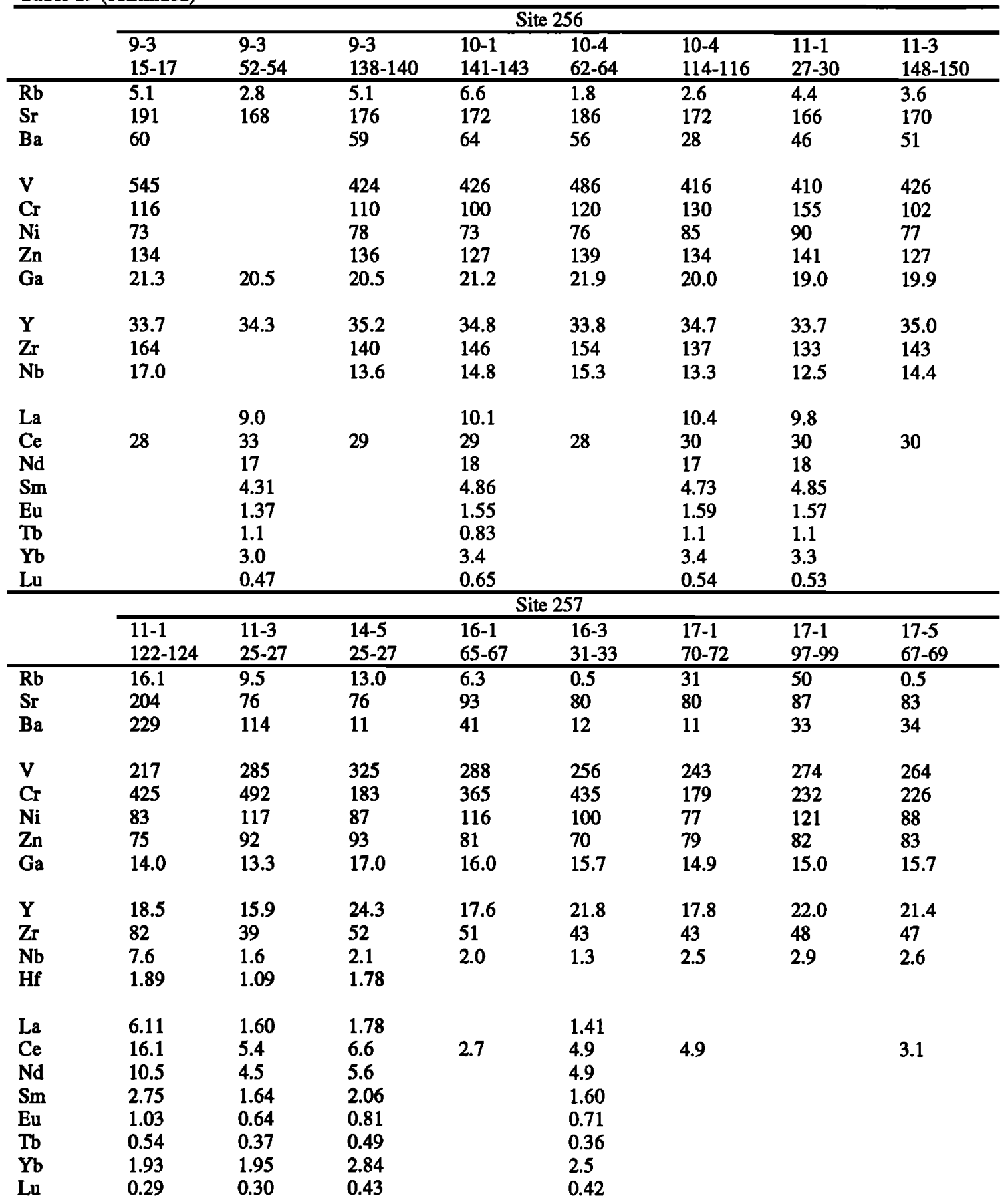

lavas of the Kerguelen Archipelago. Therefore among all lavas recovered by drilling from the eastern Indian Ocean seafloor, these Site 211 alkalic basalts are geochemically the most similar to recent lavas erupted in the Kerguelen Archipelago [Weis et al., 1993a, b]. However, Site 211 is not close to the track of the Kerguelen Plume or any other recognized plume. It is likely that lavas from this site are related to the volcanism that created the northeast trending bathymetric highs that form the Cocos-Keeling Plateau-Christmas Island complex (Figure 1).

\section{Site $256\left(2^{\circ} 27.35 ' S, 100^{\circ} 46.46 ' \mathrm{E}\right)$}

This site is in the southern Wharton Basin. Although drilled in deep water $(5361 \mathrm{~m})$, the site is near a trend of bathymetric highs extending northeast from Broken Ridge, i.e., Golden Draak knoll,
Batavia knoll, and Zeewk knoll (Figure 1) (see Figure 5 of Powell et al. [1988] for details). Based on fossils, the minimum basement age is $102 \mathrm{Ma}$; using magnetic anomalies, Powell et al. [1988] inferred a basement age of $125 \mathrm{Ma}$. Basement penetration of $19 \mathrm{~m}$ recovered $\mathrm{Fe}-\mathrm{Ti}$ rich tholeitic basalts. Both the major element and incompatible element abundances of Site 256 basalts are similar to basalts recovered from the Ninetyeast Ridge (Figure 5 and Frey et al. [1977]. Moreover, ${ }^{87} \mathrm{Sr} /{ }^{86} \mathrm{Sr},{ }^{143} \mathrm{Nd} /{ }^{144} \mathrm{Nd}$, ${ }^{206} \mathrm{~Pb} /{ }^{204} \mathrm{~Pb}$, and ${ }^{207} \mathrm{~Pb} /{ }^{204} \mathrm{~Pb}$ in Site 256 lavas overlap with the range of Ninetyeast Ridge basalts (Figures 2b, 3c and 3d).

\section{Site $257\left(3^{\circ} 59^{\prime} \mathrm{S}, 108^{\circ} 21^{\prime} \mathrm{E}\right)$}

DSDP Sites 257, 259, and 260 are near the western coast of Australia (Figure 1). This basaltic seafloor is inferred to have 
Table 1. (continued)

\begin{tabular}{|c|c|c|c|c|c|c|c|c|c|}
\hline & \multicolumn{2}{|c|}{ Site 259} & \multicolumn{2}{|c|}{ Site 260} & \multicolumn{5}{|c|}{ Site 261} \\
\hline & \begin{tabular}{l|}
$38-1$ \\
$65-67$ \\
\end{tabular} & $\begin{array}{l}41-1 \\
101-104 \\
\end{array}$ & $\begin{array}{l}18-2 \\
140-142 \\
\end{array}$ & $\begin{array}{l}20-1 \\
16-18 \\
\end{array}$ & $\begin{array}{l}33-1 \\
101-105 \\
\end{array}$ & $\begin{array}{l}34-1 \\
75-77 \\
\end{array}$ & $\begin{array}{l}35-2 \\
120-123 \\
\end{array}$ & $\begin{array}{l}36-1 \\
60-63 \\
\end{array}$ & $\begin{array}{l}39-1 \\
11-13 \\
\end{array}$ \\
\hline $\begin{array}{l}\mathbf{R b} \\
\mathbf{S r} \\
\mathrm{Ba}\end{array}$ & $\begin{array}{l}7.2 \\
91 \\
7\end{array}$ & $\begin{array}{l}12.1 \\
99\end{array}$ & $\begin{array}{l}3.6 \\
129 \\
64\end{array}$ & $\begin{array}{l}3.1 \\
112 \\
35\end{array}$ & $\begin{array}{l}20.3 \\
81\end{array}$ & $\begin{array}{l}10.9 \\
87\end{array}$ & $\begin{array}{l}14.2 \\
98 \\
20\end{array}$ & $\begin{array}{l}24.4 \\
91 \\
12\end{array}$ & $\begin{array}{l}6.1 \\
85\end{array}$ \\
\hline $\begin{array}{l}\mathrm{V} \\
\mathrm{Cr} \\
\mathrm{Ni} \\
\mathrm{Zn} \\
\mathrm{Ga}\end{array}$ & $\begin{array}{l}270 \\
148 \\
59 \\
112 \\
16.8\end{array}$ & $\begin{array}{l}260 \\
185 \\
45 \\
132 \\
17.0\end{array}$ & $\begin{array}{l}479 \\
125 \\
210 \\
178 \\
21.9\end{array}$ & $\begin{array}{l}391 \\
106 \\
51 \\
151 \\
19.8\end{array}$ & $\begin{array}{l}333 \\
172 \\
85 \\
104 \\
17.1\end{array}$ & $\begin{array}{l}323 \\
181 \\
76 \\
92 \\
17.5\end{array}$ & $\begin{array}{l}431 \\
38 \\
55 \\
213 \\
21.1\end{array}$ & $\begin{array}{l}539 \\
22 \\
53 \\
166 \\
23.2\end{array}$ & $\begin{array}{l}321 \\
165 \\
78 \\
94 \\
18.0\end{array}$ \\
\hline $\begin{array}{l}\mathrm{Y} \\
\mathrm{Zr} \\
\mathrm{Nb} \\
\mathrm{Hf}\end{array}$ & $\begin{array}{l}29.9 \\
72 \\
2.1 \\
1.92\end{array}$ & $\begin{array}{l}33.1 \\
74 \\
1.3 \\
2.04\end{array}$ & $\begin{array}{l}31.8 \\
138 \\
5.3 \\
3.14\end{array}$ & $\begin{array}{l}37.1 \\
119 \\
5.5\end{array}$ & $\begin{array}{l}30.6 \\
72 \\
0.9 \\
1.83\end{array}$ & $\begin{array}{l}33.1 \\
77 \\
1.1\end{array}$ & $\begin{array}{l}61.8 \\
205 \\
7.5 \\
5.75\end{array}$ & $\begin{array}{l}47.3 \\
176 \\
7.1\end{array}$ & $\begin{array}{l}32.4 \\
78 \\
2.0\end{array}$ \\
\hline $\begin{array}{l}\mathrm{La} \\
\mathrm{Ce} \\
\mathrm{Nd} \\
\mathrm{Sm} \\
\mathrm{Eu} \\
\mathrm{Tb} \\
\mathrm{Yb} \\
\mathrm{Lu}\end{array}$ & $\begin{array}{l}5.07 \\
10.6 \\
8.9 \\
3.09 \\
1.03 \\
0.63 \\
3.04 \\
0.43 \\
\end{array}$ & $\begin{array}{l}4.39 \\
12.8 \\
8.9 \\
3.20 \\
1.17 \\
0.83 \\
3.27 \\
0.50 \\
\end{array}$ & $\begin{array}{l}7.60 \\
14.9 \\
10.1 \\
3.95 \\
1.46 \\
0.79 \\
3.31 \\
0.47 \\
\end{array}$ & $\begin{array}{l}6.0 \\
17 \\
9.7 \\
3.75 \\
1.21 \\
- \\
4.1 \\
0.65\end{array}$ & $\begin{array}{l}1.99 \\
7.7 \\
7.1 \\
2.76 \\
1.04 \\
0.70 \\
3.45 \\
0.53 \\
\end{array}$ & $\begin{array}{l}2.34 \\
11 \\
7.1 \\
3.11 \\
1.03 \\
0.73 \\
3.4 \\
0.62 \\
\end{array}$ & $\begin{array}{l}8.35 \\
29.6 \\
23.5 \\
7.84 \\
2.62 \\
1.63 \\
5.96 \\
0.85 \\
\end{array}$ & 17.9 & $\begin{array}{l}2.45 \\
9 \\
7.8 \\
3.16 \\
1.17 \\
0.79 \\
3.90 \\
0.60 \\
\end{array}$ \\
\hline
\end{tabular}

In parts per million. Sample designation indicates core and section number followed by an interval in centimeters. Data for REE (Lu through $\mathrm{L}$ ) and $\mathrm{Hf}$ are by instrumental neutron activation at MIT; data for other elements are determined by X ray fluorescence at University of Massachusetts, Amherst. When Ce abundances are not accompanied by other REE data, Ce was determined by XRF. For discussion of precision and accuracy, see Frey et al. [1991].

formed at the northeast-southwest oriented spreading ridge that separated Greater India from Australia [e.g., Markl, 1974; Veevers et al., 1974; Rundle et al., 1974; Fullerton et al., 1989]. At Site 257, Middle Albian -106-110 Ma sediments occur $13 \mathrm{~m}$ above the basaltic basement. Basement penetration was $64.5 \mathrm{~m}$. Although basalts from core 11 have $-100 \mathrm{Ma} \mathrm{K} / \mathrm{Ar}$ ages roughly consistent with the age of the overlying sediments, much older K/Ar ages (157 to $196 \mathrm{Ma}$ ) were obtained from basalts lower in the core [Rundle et al., 1974]. Based on extrapolation of magnetic anomalies, inferred basement ages range from 110 to $130 \mathrm{Ma}$ (Powell et al. [1988] and Luyendyk and Davies [1974], respectively). Most of the basalts from this core have incompatible element abundance ratios intermediate between SEIR MORB and lavas from the Ninetyeast Ridge (Figure 5). Their isotopic ratios overlap with the Indian Ocean MORB field (Figures $2 b, 3 c$ and $3 d$ ). In contrast, the uppermost basalts (core 11, section 1, Table 1) have $\mathrm{La} / \mathrm{Yb}, \mathrm{Ce} / \mathrm{Y}$ and $\mathrm{Zr} / \mathrm{Nb}$ similar to basalts from Site 256 and lavas from the Ninetyeast Ridge (see Fleet et al. [1976] and Figure 5). The uppermost lava is also similar to Ninetyeast Ridge lavas in $\mathrm{Sr}$ and $\mathrm{Nd}$ isotopic ratios, although its combination of Sr-Nd is not within Ninetyeast Ridge field (Table 2 and Figure $2 \mathrm{~b}$ ). It also has higher $\mathrm{Pb}$ isotopic ratios than the depleted lavas from Site 257 (Table 2). Although the accuracy of the K-Ar ages is unknown, it is intriguing that the $K$ Ar age ( $100 \mathrm{Ma}$ [Rundle et al., 1974]) of the uppermost basalts is also similar to the minimum age inferred for the enriched basalts at Site 256. However, like other Site 257 lavas, the enriched basalt has relatively low ${ }^{206} \mathrm{~Pb} /{ }^{204} \mathrm{~Pb}$ (17.57). This is much lower than that found in lavas from the Ninetyeast Ridge and Indian OIB. Thus the youngest Indian ocean crust sampled at Site 257 is geochemically enriched, similar to lavas subsequently erupted on the Ninetyeast Ridge. However, all basalts at Site 257 plot within the Indian Ridges field in $\mathrm{Pb}-\mathrm{Pb}$ diagrams (Figures $3 \mathrm{c}$ and 3d) and have the low ${ }^{206} \mathrm{~Pb} /{ }^{204} \mathrm{~Pb}$ that is characteristic of many Indian Ocean MORB and which has not been found in lavas related to the Kerguelen Plume.

\section{Site $259\left(29^{\circ} 37^{\prime} \mathrm{S}, 112^{\circ} 42\right.$ 'E)}

Based on the age of overlying earliest Aptian sediments, basement at this site is older than $\sim 112 \mathrm{Ma}$; Powell et al. [1988] used magnetic anomalies to infer a basement age of $125 \mathrm{Ma}$. As at Site 257, the oceanic crust at Site 259 is presumed to have formed at a northeast-southwest oriented ridge. The Site 259 lavas have $\mathrm{La} / \mathrm{Yb}, \mathrm{Ce} / \mathrm{Y}$, and $\mathrm{Zr} / \mathrm{Nb}$ typical of depleted SEIR MORB (Figure 5). The two analyzed samples are geochemically similar, except for a difference in $\mathrm{Zr} / \mathrm{Nb}$ which probably reflects analytical error at these low $\mathrm{Nb}$ contents $(-2 \pm 0.6 \mathrm{ppm}$, Table 1 [Rhodes et al., 1990]). The ${ }^{87} \mathrm{Sr} /{ }^{86} \mathrm{Sr}$ and ${ }^{143} \mathrm{Nd} /{ }^{144} \mathrm{Nd}$ overlap with the high ${ }^{87} \mathrm{Sr} /{ }^{86} \mathrm{Sr}$ end of the recent Indian Ocean MORB field; the offset of the age-corrected values to lower ${ }^{143} \mathrm{Nd} /{ }^{144} \mathrm{Nd}$ and ${ }^{87} \mathrm{Sr} /{ }^{86} \mathrm{Sr}$ (Figure 2b) is consistent with aging of a depleted mantle (MORB) source. In Pb isotopes, both lavas have ${ }^{206} \mathrm{~Pb} /{ }^{204} \mathrm{~Pb}$ at the high end of the Indian Ocean MORB field. However, like the depleted basalts from Site 212 and the enriched basalt from Site 213, these Site 259 lavas have ${ }^{207} \mathrm{~Pb} /{ }^{204} \mathrm{~Pb}$ greater than any lava from the Kerguelen Archipelago (Figures $3 c$ and $3 d$ ), with $\Delta 7 / 4$ of $14.0-14.3$ and $\Delta 8 / 4$ of 32.7-60.7.

\section{Site $260\left(16^{\circ} 9^{\prime} \mathrm{S}, 110^{\circ} 18^{\prime} \mathrm{E}\right)$}

Like the basement at Sites 257 and 259, oceanic crust at Site 260 in the northeast Indian Ocean (Figure 1) is inferred to have 


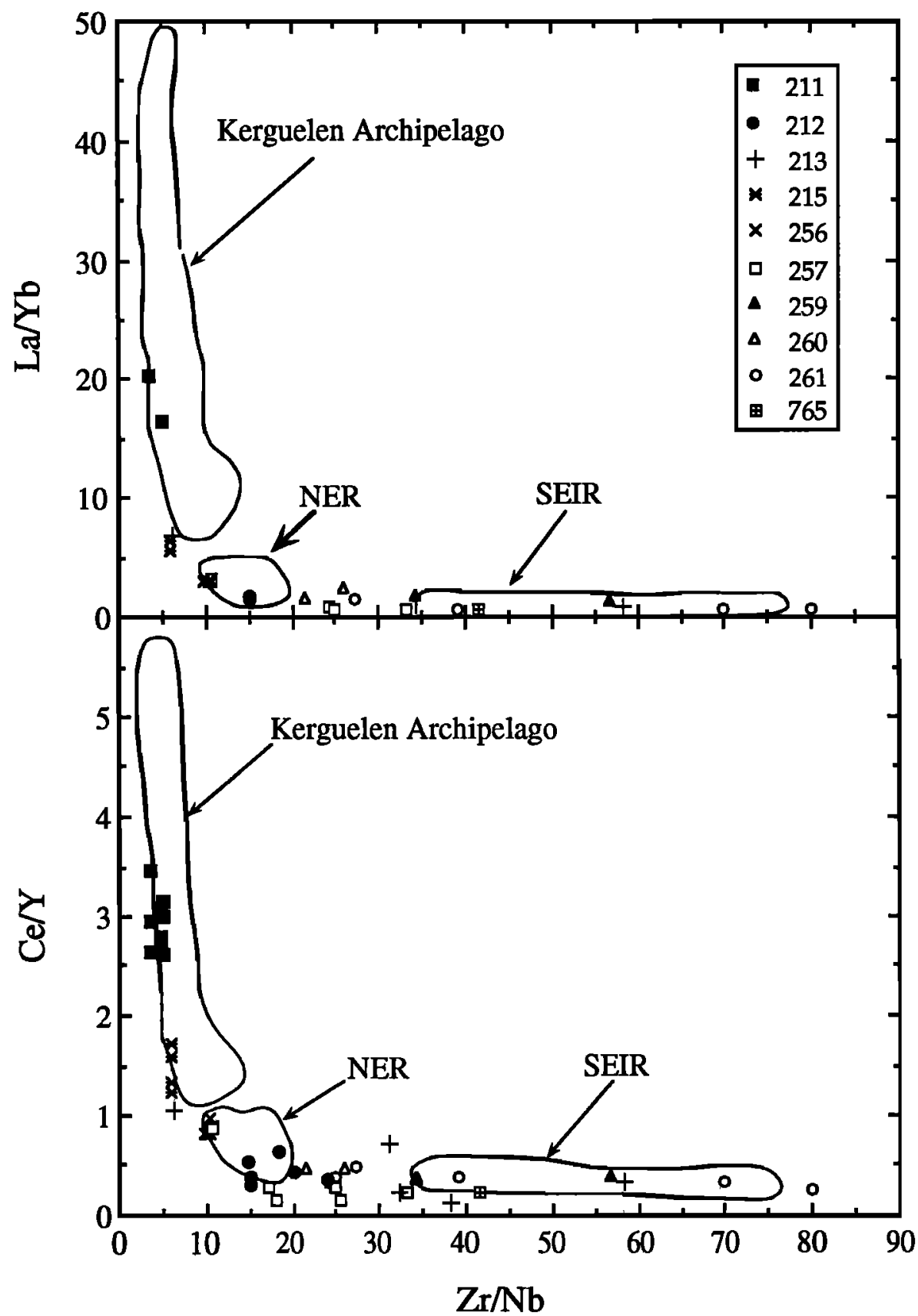

Figure 5. $\mathrm{Ce} / \mathrm{Y}$ and $\mathrm{La} / \mathrm{Yb}$ versus $\mathrm{Zr} / \mathrm{Nb}$ in basalts from the eastern Indian Ocean seafloor (data from Table 1 and average for Site 765 lavas from Ishiwatari [1992] compared to fields defined by lavas from the Kerguelen Archipelago [Storey et al., 1988; Gautier et al., 1990; Weis et al., 1993a], Ninetyeast Ridge [Frey et al., 1991], and Southeast Indian Ridge (SEIR MORB) [Price et al., 1986]; the range for Kerguelen Archipelago lavas from low to high $\mathrm{La} / \mathrm{Yb}$ and $\mathrm{Ce} / \mathrm{Y}$ reflects the evolution from older, $\approx 25 \mathrm{Ma}$, transitional basalts to younger, $<10 \mathrm{Ma}$, highly alkaline lavas. We use these elements because they are relatively unaffected by postmagmatic processes. The selected ratios involve elements of different incompatibility and they illustrate the diversity of these DSDP lavas. These ratios clearly distinguish depleted MORB from OIB and enriched MORB; La/Yb indicates the slope of a chondrite-normalized REE plot ( $\mathrm{La} / \mathrm{Yb}$ is $\approx 1.48$ in chondrites); $\mathrm{Ce} / \mathrm{Y}(\approx 0.39$ in chondrites) is also plotted because there are more data for these elements (Table 1). These incompatible element ratios show that most of the basement sites in the eastern Indian Ocean have recovered basalts which are intermediate between depleted MORB and Ninetyeast Ridge lavas. Only Site 211 and Site 215 basalts are within the field of lavas from the Kerguelen Archipelago.

formed from the northeast-southwest spreading center that separated Greater India from Australia. At Site 260, the recovered basalt is interpreted to be a sill that is overlain by $105 \mathrm{Ma}$ sediments. Although $9 \mathrm{~m}$ of basalt was penetrated, only
$0.5 \mathrm{~m}$ of core was recovered. Similar to basalts from Site 257 , $\mathrm{Ce} / \mathrm{Y}, \mathrm{Zr} / \mathrm{Nb}$ and $\mathrm{La} / \mathrm{Yb}$ in the Site 260 lava are intermediate between SEIR MORB and lavas from the Ninetyeast Ridge (Figure 5). Consistent with this result, measured ${ }^{87} \mathrm{Sr} /{ }^{86} \mathrm{Sr}$ and 
Table 2. $\mathrm{Sr}, \mathrm{Nd}$, and $\mathrm{Pb}$ Isotopic Data and $\mathrm{Pb}$ and $\mathrm{U}$ Concentrations by Isotope Dilution in DSDP Basals From the Eastern Indian Ocean

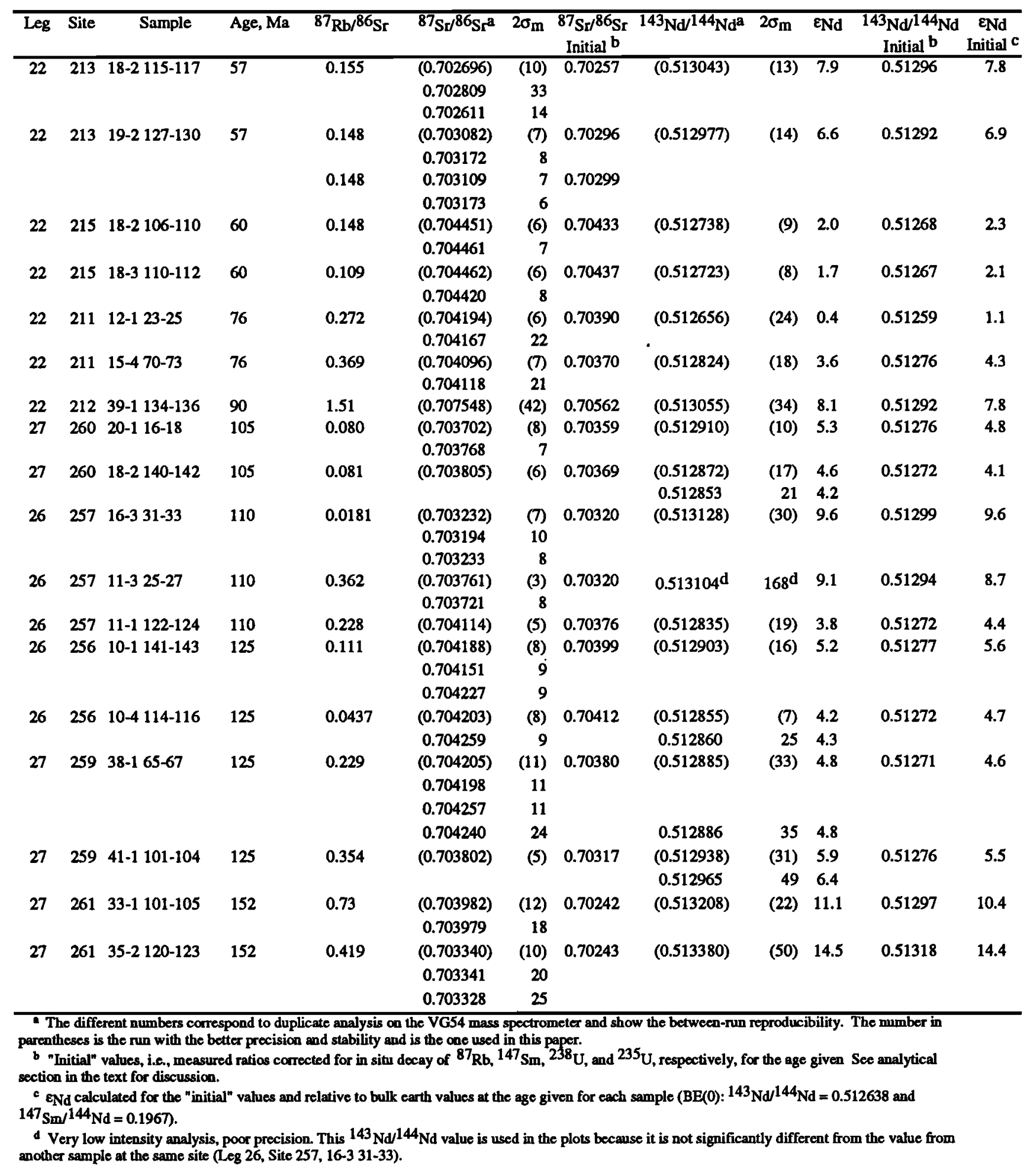

${ }^{143} \mathrm{Nd} /{ }^{144} \mathrm{Nd}$ overlap with the enriched end of the MORB field (Figure $2 \mathrm{~b}$ ) and like the Site 259 lavas, the offset of age corrected $143_{\mathrm{Nd}} /{ }^{144} \mathrm{Nd}$ and ${ }^{87} \mathrm{Sr} /{ }^{86} \mathrm{Sr}$ from the field for recent MORB (Figure $2 \mathrm{~b}$ ) is consistent with aging of a depleted mantle source. The $\mathrm{Pb}$ isotopic characteristics of these two Site 260 samples are unusual (Figure 3), one sample has relatively low initial ${ }^{206} \mathrm{~Pb} /{ }^{204} \mathrm{~Pb}(-17.5)$ and a high ${ }^{207} \mathrm{~Pb} /{ }^{204} \mathrm{~Pb}$ (15.5), whereas the other has unusually high initial ${ }^{206} \mathrm{~Pb} /{ }^{204} \mathrm{~Pb}(20.3)$ and ${ }^{207} \mathrm{~Pb} /{ }^{204} \mathrm{~Pb}$ (15.8) (not plotted on Figure 3).

\section{Site $261\left(12^{\circ} 57^{\prime} \mathrm{S}, 117^{\circ} 54^{\prime} \mathrm{E}\right)$}

This site in the northern Argo Abyssal Plain penetrated $47 \mathrm{~m}$ of basalt below sediments of $152 \mathrm{Ma}$ (Figure 1). Thus these basalts are the oldest recovered by DSDP in the eastern Indian Ocean, and they are similar in age to the $155 \mathrm{Ma}$ basalts recovered at ODP Site 765 in the southern Argo Abyssal Plain [Ludden and Dionne, 1992]. The basaltic core can be divided into three units [Robinson and Whitford, 1974]. The uppermost unit $A$ is a 10-m 
Table 2. (continued)

\begin{tabular}{|c|c|c|c|c|c|c|c|c|}
\hline $\mathrm{Pb} \mathrm{ppm}$ & U ppm & ${ }^{238} \mathrm{U} /{ }^{204} \mathrm{~Pb}$ & ${ }^{206} \mathrm{~Pb} / 204 \mathrm{~Pb}$ & ${ }^{207} \mathrm{~Pb} /{ }^{204} \mathrm{~Pb}$ & ${ }^{208} \mathrm{~Pb} / 204 \mathrm{~Pb}$ & ${ }^{206} \mathrm{~Pb} / 204 \mathrm{~Pb}$ & ${ }^{207} \mathrm{~Pb} /{ }^{204} \mathrm{~Pb}$ & $\mathrm{Ce} / \mathrm{Pb}$ \\
\hline & & & & & & Initial b & Initial b & \\
\hline 0.07 & 0.01 & 9.0 & 18.17 & 15.491 & 38.01 & 18.09 & 15.49 & 108.6 \\
\hline 0.29 & 0.08 & 17.7 & 18.66 & 15.66 & 38.84 & 18.50 & 15.65 & 21.7 \\
\hline 0.37 & 0.1 & & & & & & & \\
\hline 0.76 & 0.21 & 17.5 & 18.15 & 15.548 & 38.42 & 17.99 & 15.54 & 42.9 \\
\hline 1.02 & 0.28 & 17.3 & 18.10 & 15.533 & 38.32 & 17.94 & 15.53 & 35.3 \\
\hline 0.94 & 0.29 & 19.7 & 18.48 & 15.582 & 38.77 & 18.25 & 15.57 & 75.2 \\
\hline 1.2 & 0.09 & 4.80 & 18.65 & 15.557 & 38.90 & 18.59 & 15.55 & 64.4 \\
\hline 0.17 & 0.06 & 22.6 & 18.80 & 15.673 & 38.77 & 18.48 & 15.66 & 29.4 \\
\hline 0.18 & 0.44 & 163 & 22.85 & 15.911 & 38.07 & 20.29 & 15.79 & 94.4 \\
\hline 0.28 & 0.15 & 33.6 & 18.05 & 15.579 & 37.96 & 17.52 & 15.55 & 53.2 \\
\hline 0.3 & 0.15 & 31.3 & 18.03 & 15.544 & 37.92 & 17.54 & 15.52 & \\
\hline 0.06 & 0.01 & 14.3 & 17.72 & 15.386 & 37.35 & 17.47 & 15.37 & 81.7 \\
\hline 0.12 & 0.07 & 36.3 & 18.06 & 15.439 & 37.47 & 17.44 & 15.41 & 45.0 \\
\hline 0.76 & 0.95 & 80 & 19.19 & 15.627 & 38.01 & 17.82 & 15.56 & 21.2 \\
\hline 0.13 & 0.12 & 61 & 19.17 & 15.621 & 39.33 & 17.98 & 15.56 & 223.1 \\
\hline 0.21 & 0.11 & 33.9 & 19.05 & 15.58 & 39.2 & 18.39 & 15.55 & 142.9 \\
\hline 0.41 & 0.05 & 7.7 & 18.26 & 15.61 & 38.31 & 18.11 & 15.60 & 25.8 \\
\hline 0.33 & 0.03 & 4.82 & 18.58 & 15.648 & 38.42 & 18.49 & 15.64 & 38.8 \\
\hline 0.33 & 0.03 & 4.82 & 18.58 & 15.635 & 38.44 & 18.50 & 15.63 & \\
\hline 0.12 & 0.06 & 30.9 & 18.46 & 15.537 & 37.62 & 17.72 & 15.50 & 64.2 \\
\hline 0.7 & 0.38 & 34.6 & 18.72 & 15.634 & 38.39 & 17.89 & 15.59 & 42.3 \\
\hline
\end{tabular}

coarse-grained sill with a highly depleted MORB composition (Figure 5) whose ${ }^{87} \mathrm{Sr} /{ }^{86} \mathrm{Sr}$ and ${ }^{143} \mathrm{Nd} \mathrm{l}^{144} \mathrm{Nd}$ are at the depleted end of the Indian Ocean MORB field (Figure 2b). Although the older, underlying units $B$ and $C$ are less depleted in incompatible element abundances than unit $A$, the sample from unit $B$ has equally low ${ }^{87} \mathrm{Sr} /{ }^{86} \mathrm{Sr}$ and even higher ${ }^{143} \mathrm{Nd} /{ }^{144} \mathrm{Nd}$ (Table 2 and Figure 2b). These Site 261 lavas have $\mathrm{Sr}$ and $\mathrm{Nd}$ isotopic signatures similar to those of Site 765 basalts [Ludden and Dionne, 1992], and they have lower ${ }^{87} \mathrm{Sr} /{ }^{86} \mathrm{Sr}$ and higher $143 \mathrm{Nd} / 144 \mathrm{Nd}$ than basalts from the other eastern Indian Ocean sites studied in this paper (Figure $2 b$ ). Site 261 lavas have the low ${ }^{206} \mathrm{~Pb} / 204 \mathrm{~Pb}$ ratios typical of some Indian Ocean MORB, but they have relatively high ${ }^{207} \mathrm{~Pb} /{ }^{204} \mathrm{~Pb}$ (15.50 to 15.59), although not as high as in depleted MORB samples from Sites 212 and 259 (Figure 3c).

\section{Discussion}

\section{Occurrence of Enriched MORB}

At three of the studied DSDP sites, the recovered basalts are highly enriched in incompatible elements relative to MORB. At Sites 215 and 256, the tholeiitic lavas have isotopic and incompatible element ratios similar to lavas associated with the Kerguelen Plume (Figures 2b, 3c, 3d and 5). Because the Ninetyeast Ridge, which is interpreted to be a hotspot track related to the Kerguelen Plume [e.g., Weis et al., 1992], is only $240 \mathrm{~km}$ east of Site 215 , it is conceivable that the $>60 \mathrm{Ma}$ basaltic basement at Site 215 is related to the Ninetyeast Ridge. Site 256 is located on a northeast trending series of bathymetric highs emanating from Broken Ridge (Figure 1), which formed as the northern portion of the Kerguelen Plateau. This very large 
plateau is also interpreted to be a manifestation of the Kerguelen Plume [e.g., Davies et al., 1989; Weis et al., 1989a; Salters et al., 1991; Storey et al., 1992; Muller et al., 1993]. Ages for lavas from the Kerguelen Plateau range from 85 to $118 \mathrm{Ma}$ [Leclaire et al., 1987; Whitechurch et al., 1992; Pringle et al., 1994], whereas lavas from Broken Ridge have ages ranging from 63 to $89 \mathrm{Ma}$ [Duncan, 1991]. Because of their geochemical similarities with lavas related to the Kerguelen Plume and their minimum 102 $\mathrm{Ma}$ and maximum $125 \mathrm{Ma}$ age, Site 256 lavas may represent early volcanism related to the Kerguelen Plume.

In contrast, the enriched alkalic lavas at Site 211 in the northern Wharton Basin cannot be directly related to the Kerguelen Plume. Site 211 is located on a series of northeast trending bathymetric bighs whose origin is unknown, and their strike is not consistent with the trace of a known hotspot. The alkalic basalts at this site, however, have compositional similarities to the much younger basalts forming the Kerguelen Archipelago (Figure 5). Although lavas from nearby Christmas Island have higher ${ }^{206} \mathrm{~Pb} /{ }^{204} \mathrm{~Pb}$ than Kerguelen lavas, the $\mathrm{Pb}$ isotopic fields defined by lavas from Site 211 overlap the Kerguelen field (Figures $3 b$ and $3 c$ ). In addition, a basement sample from this site bas $\mathrm{Sr}$ and $\mathrm{Nd}$ isotopic ratios close to the low ${ }^{87} \mathrm{Sr} /{ }^{86} \mathrm{Sr}$-high ${ }^{143} \mathrm{Nd} /{ }^{144} \mathrm{Nd}$ end of the range defined by lavas from the Ninetyeast Ridge and Kerguelen Archipelago (Figure 2b). Therefore lavas with geochemical characteristics similar to lavas associated with the Kerguelen Plume have erupted in locations where the volcanism cannot be directly related to the Kerguelen Plume.

Lavas at two sites (257 and 213) range widely in ratios of incompatible elements but have $\mathrm{Sr}$ and $\mathrm{Nd}$ isotopic ratios close to or within the Indian MORB field. At Site 257, close to the southwest coast of Australia (Figure 1), the uppermost lavas are compositionally very similar to the enriched lavas at site 256 . An important difference is that all of the relatively old Site 257 basalts have low initial ${ }^{206} \mathrm{~Pb} /{ }^{204} \mathrm{~Pb}(<17.8)$. This feature is a distinctive characteristic of some recent Indian Ocean MORB, which has not been observed in lavas from the Kerguelen Archipelago (Figures $3 c$ and 3d). Site 213 is located in a region where the east-west magnetic lineations are remarkably clear (Figure 1), and the basement is inferred to have been formed from an east-west spreading ridge axis well north of the Kerguelen Plume [e.g., Royer et al., 1991]. Consistent with this interpretation, most of the Site 213 core is depleted MORB. However, the lowermost basalt in this core is enriched in incompatible elements (Table 1 and Figures 4 and 5) and has anomalous $\mathrm{Pb}$ isotope ratios that are much higher than Indian Ocean MORB. In fact, ${ }^{207} \mathrm{~Pb} /{ }^{204} \mathrm{~Pb}$ even exceeds that measured in lavas from the Kerguelen Archipelago (Figure $3 \mathrm{c}$ and Table 2).

\section{Occurrence of Depleted MORB}

Most of the basalts from six DSDP sites (Sites 212, 213, 257, 259, 260, and 261) and ODP Site 765, ranging in inferred ages from $\sim 56$ to $155 \mathrm{Ma}$, are geochemically similar to Indian Ocean MORB. They have relatively low $\mathrm{La} / \mathrm{Yb}$ and $\mathrm{Ce} / \mathrm{Y},\left({ }^{87} \mathrm{Sr} /{ }^{86} \mathrm{Sr}\right)$ $<0.7038$ (the Site 212 sample is an exception) and $\left({ }^{143} \mathrm{Nd} /{ }^{144} \mathrm{Nd}\right)_{\mathrm{i}}>0.5127$ and $\left(\varepsilon_{\mathrm{Nd}}\right)_{\mathrm{i}}>4.1$ (Figures 2 and 5$)$. These basalts, however, have diverse $\mathrm{Pb}$ isotopic characteristics (Figure 3). Lavas associated with the Kerguelen Plume, i.e., those forming the Kerguelen Archipelago and Ninetyeast Ridge, have initial ${ }^{206} \mathrm{~Pb} /{ }^{204} \mathrm{~Pb}$ of 17.67 to 18.71 (Figure 6a). Enriched and depleted lavas from DSDP sites with ages of $<125 \mathrm{Ma}$ (Sites $213,215,211,212,256$, and 259 ) bave ${ }^{206} \mathrm{~Pb} /{ }^{204} \mathrm{~Pb}$ within this range (Figure 6a). These lavas contrast with some recent Indian Ocean MORB, some lavas recovered from the Kerguelen Plateau, and some of the lavas from the oldest eastern Indian Ocean drill sites, Sites 257 and 765 , which range to much lower ${ }^{206} \mathrm{~Pb} /{ }^{204} \mathrm{~Pb}$ (to 17.30 , Figure 6a). Thus unusually low ${ }^{206} \mathrm{~Pb} /{ }^{204} \mathrm{~Pb}$ is characteristic of both recent Indian Ocean MORB and relatively old seafloor in the eastern Indian Ocean, but it is not characteristic of $<82 \mathrm{Ma}$ lavas associated with the Kerguelen Plume (Figure 6a). Similarly, relatively high $\Delta 8 / 4$ values are associated with lavas from the Kerguelen Plume and lavas at the seven DSDP sites ranging in age from -56 to $125 \mathrm{Ma}$ (Sites 213, $215,211,212,260,256$, and 259). In contrast, lavas from DSDP Sites 257 and 261 have much lower $\Delta 8 / 4$ (Figure $6 \mathrm{~b}$ ). Lavas from DSDP Site 261 and ODP Site 765 are the oldest Indian Ocean seafloor studied, and they also have higher $\left({ }^{143} \mathrm{Nd} /{ }^{144} \mathrm{Nd}\right),>0.51285$, than lavas associated with the Kerguelen Plume; thus they are similar to recent Indian MORB (Figure 6c).

\section{Source of Anomalously High ${ }^{207} \mathrm{~Pb} /{ }^{204} \mathrm{~Pb}$}

At three of the DSDP sites studied, some of the basalts have anomalously high ${ }^{207} \mathrm{~Pb} /{ }^{204} \mathrm{~Pb}$ (Sites 212,213 , and 259), i.e., higher than Indian Ocean MORB and lavas from the Kerguelen Archipelago (Figure 3c). Conversely, in the ${ }^{208} \mathrm{~Pb} /{ }^{204} \mathrm{~Pb}$ versus ${ }^{206} \mathrm{~Pb} /{ }^{204} \mathrm{~Pb}$ diagram (Figure 3d), most of these samples plot within the Kerguelen and Ninetyeast Ridge fields. In an oceanic environment, only sediments have such high ${ }^{207} \mathrm{~Pb} /{ }^{204} \mathrm{~Pb}$. The Site 212 basalt has also a high age-corrected ${ }^{87} \mathrm{Sr} /{ }^{86} \mathrm{Sr}(0.70741)$ indicating that some of the postmagmatic phases were not removed by acid leaching.

In $\mathrm{Pb}-\mathrm{Pb}$ diagrams (Figure $3 \mathrm{c}$ ), the samples with anomalous ${ }^{207} \mathrm{~Pb} /{ }^{204} \mathrm{~Pb}$ plot on trends between the Indian MORB field and the field for Indian Ocean sediments [Ben Othman et al., 1989; Vroon et al., 1993]. In general, abundance ratios of $\mathrm{Ce} / \mathrm{Pb}$ are unusually high in these eastern Indian Ocean basalts (12 of 18 samples have $\mathrm{Ce} / \mathrm{Pb}>40$, Table 2, compared to a typical MORB ratio of $\sim 25$ [Hofmann et al., 1986]). Samples with anomalously high ${ }^{207} \mathrm{~Pb} /{ }^{204} \mathrm{~Pb}$, however, have lower $\mathrm{Ce} / \mathrm{Pb},<40$ (Table 2). Mixing calculations by Ben Othman et al. [1989] in their study of sediment recycling into the mantle indicate that the addition of only $1 \%$ sediment to the mantle leads to low $\mathrm{Ce} / \mathrm{Pb}$ and anomalously high ${ }^{207} \mathrm{~Pb} /{ }^{204} \mathrm{~Pb}$. We conclude that these samples may contain small amounts of sediment that were not removed by acid leaching. Therefore we do not use these high ${ }^{207} \mathrm{~Pb} /{ }^{204} \mathrm{~Pb}$ values in our discussion of source components.

\section{Origin of the Dupal Anomaly}

Following numerous previous studies starting with Subbarao and Hedge [1973], Dupre and Allegre [1983] showed that many oceanic island basalts in the Indian Ocean have distinctive Sr, Nd, and $\mathrm{Pb}$ isotopic ratios, which Hart [1984] termed the Dupal anomaly. This large distinctive isotopic domain is centered at $-30^{\circ} \mathrm{S}$ and is defined by ${ }^{87} \mathrm{Sr} /{ }^{86} \mathrm{Sr}>0.705$ and $\Delta 8 / 4>+60$ [Hart, 1988]. Hart [1988] noted that only three localities in the northern hemisphere have lavas with a Dupal signature. The distinctive isotopic characteristics of Indian Ocean MORB in comparison to Atlantic and Pacific MORB are interpreted to result from a Dupal component incorporated into the Indian Ocean asthenosphere. This isotopically distinctive asthenosphere has also been inferred to be the source for lavas erupted in the marginal basins of the western Pacific. Hickey-Vargas et al. [1995] conclude that Indian Ocean asthenosphere, perhaps flowing in along the northern 

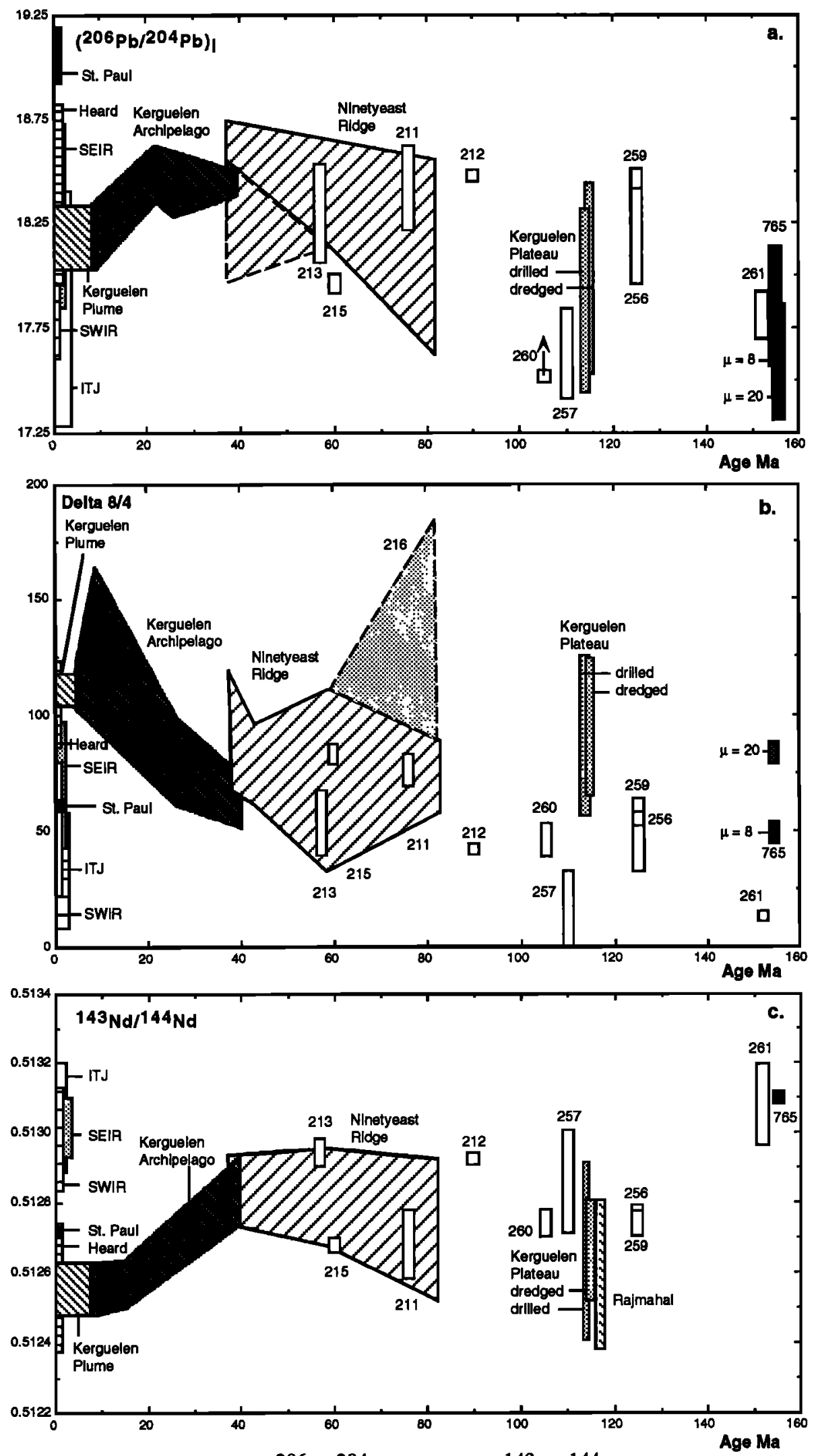

Figure 6. (opposite) Isotopic parameters $\left({ }^{206} \mathrm{~Pb} /{ }^{204} \mathrm{~Pb}\right)_{i}, \Delta 8 / 4$ and $\left({ }^{143} \mathrm{Nd} /{ }^{144} \mathrm{Nd}\right)_{i}$ versus age for eastern Indian Ocean seafloor. (a) All ${ }^{206} \mathrm{~Pb} /{ }^{204} \mathrm{~Pb}$ ratios are age-corrected. The upward arrow for Site 260 indicates that the ratio for a sill in this core is off-scale at 20.3. Because $\mathrm{U}$ and $\mathrm{Pb}$ data are not available for all lavas from Site 765 , corrected ratios are shown for two assumed ${ }^{238} \mathrm{U} /{ }^{204} \mathrm{~Pb}$ ratios $(\mathrm{u}=8$ and 20 ). (b) The $\Delta$ values for the older basalts are maximum values because ${ }^{206} \mathrm{~Pb} /{ }^{204} \mathrm{~Pb}$ ratios have been age corrected, but the ${ }^{208} \mathrm{~Pb} /{ }^{204} \mathrm{~Pb}$ ratios have not been corrected because precise Th abundance data are not available. (c) All ${ }^{143} \mathrm{Nd} /{ }^{144} \mathrm{Nd}$ ratios are agecorrected. ITJ, SWIR, and SEIR indicate Indian Ocean triple junction, Southwest Indian Ridge, and Southeast Indian Ridge, respectively. Dashed lines in Ninetyeast Ridge field (Figures 6a and 6b) are defined by data from DSDP Site 216 [Frey and Weis, 1995]. Field labeled Kerguelen Plume is from Weis et al. [1993a]. Data for Site 765 are revised from Ludden and Dionne [1992; J.N. Ludden, personal communication, 1995]; data from Heard Island are from Barling et al. [1994]; all other data sources are as indicated in caption for Figure $2 \mathrm{~b}$. 
boundary of Australia prior to $\sim 50 \mathrm{Ma}$, was an important source component for these western Pacific lavas. Of the 10 drill sites that recovered basalts from the eastern Indian Ocean, lavas at seven sites $(<125 \mathrm{Ma}$ ) have $\Delta 8 / 4>33$ (range 33 to 85 ). In contrast, the presence of a Dupal component is not obvious in the oldest lavas from the eastern Indian Ocean seafloor; for example, lavas from Sites 261 and 765 ( 152 to $155 \mathrm{Ma}$ ) have very high ${ }^{143} \mathrm{Nd} /{ }^{144} \mathrm{Nd}$ (Figure $6 \mathrm{c}$ ), and low ${ }^{87} \mathrm{Sr} /{ }^{86} \mathrm{Sr}$ (Figure $2 \mathrm{~b}$ and Ludden and Dionne [1992]) and lavas from Site 261 have very low $\Delta 8 / 4$ (Figure $6 \mathrm{~b}$ ). Therefore, in the eastern Indian Ocean seafloor, there is evidence for a Dupal component that has persisted since $\approx 125 \mathrm{Ma}$. We emphasize that this $125 \mathrm{Ma}$ age is not rigorously constrained because the ages of basement lavas at these DSDP sites have not been reliably determined. The earliest manifestation of Dupal characteristics in dated lavas is in the oldest lavas associated with the Kerguelen Plume; i.e., the 110$118 \mathrm{Ma}$ lavas forming the Kerguelen Plateau. Because $\approx 118 \mathrm{Ma}$ corresponds to the first unambiguous evidence of activity of the Kerguelen Plume, we infer that the Dupal anomaly is carried by the Kerguelen Plume and that the source of this anomaly is deep within the mantle [e.g., Castillo, 1988; Weis et al., 1989a].

The origin of the geochemical characteristics of the Dupal anomaly [Dupré and Allegre, 1983; Hart, 1984], with its subequatorial concentration, is an unresolved problem [Hart, 1988]. Most geochemical models require a long isolation time (1 to $2 \mathrm{Gyr}$ ) to develop the isotopic characteristics of OIB. A commonly proposed origin for the Dupal anomaly is recycling of subcontinental lithosphere into the mantle by a delamination process [Hart et al., 1986; Hawkesworth et al., 1986; Hart 1988; Sun and McDonough, 1989]. We propose that the concentration of the Dupal anomaly to the subequatorial southern hemisphere may be directly connected to the nearly fixed location of the African continent (and by extension the Gondwana supercontinent). This would allow either for a thermal blanketing [Anderson, 1982] or an underplating (thickening) of the lithosphere, which would favor delamination. An important aspect of the Indian Ocean and the eastern Atlantic Ocean is the occurrence of major flood basalt provinces on the surrounding continents [White and McKenzie, 1989]. Because continental flood basalt provinces reflect a large magmatic output in a relatively short interval of time, they could generate a thickened lithospheric mantle. This thickened lithospheric mantle could subsequently delaminate cold lithosphere into the asthenospheric mantle through a process of thermal erosion or delamination. The oldest flood basalts in this region are the Karoo and Ferrar, which erupted in the middle to early Jurassic. Delamination resulting from these volcanic events preceded the first manifestations of the Kerguelen Plume by $<100 \mathrm{Myr}$.

\section{Source of Anomalously Low ${ }^{206} \mathrm{~Pb} /{ }^{204} \mathrm{~Pb}$}

A distinctive feature of some recent Indian Ocean MORB is relatively low ${ }^{206} \mathrm{~Pb} /{ }^{204} \mathrm{~Pb}$, e.g., lavas from the Triple Junction and portions of the SWIR (Figure 6a). Lavas from Sites 257 and 765 also range to low ${ }^{206} \mathrm{~Pb} /{ }^{204} \mathrm{~Pb}$ (Figure 6a). The origin of the mantle component with low ${ }^{206} \mathrm{~Pb} /{ }^{204} \mathrm{~Pb}$ is uncertain. Mahoney et al. [1992] discussed two alternative possibilities: 1) Gondwana Precambrian lithosphere or (2) mantle plumes. The ${ }^{206} \mathrm{~Pb} /{ }^{204} \mathrm{~Pb}$ values of Indian Ocean basalts as a function of eruption age are important in evaluating these alternatives. Evidence against a plume origin is that recent lavas related to Indian Ocean plumes do not have similarly low ${ }^{206} \mathrm{~Pb} /{ }^{204} \mathrm{~Pb}$ [Mahoney et al., 1992]. We favor a continental lithosphere origin for the low ${ }^{206} \mathrm{~Pb} /{ }^{204} \mathrm{~Pb}$ because (1) some continental basalts from Madagascar [Mahoney et al., 1992] and western Australia [Frey et al., 1996] have unusually low ${ }^{206} \mathrm{~Pb} /{ }^{204} \mathrm{~Pb}$; (2) some of the oldest basalts (110 to $155 \mathrm{Ma})$ in the eastern Indian Ocean have lower ${ }^{206} \mathrm{~Pb} /{ }^{204} \mathrm{~Pb}$ than lavas associated with Indian Ocean plumes (e.g., Figure 6a and Mahoney et al. [1995]) and (c) the low ${ }^{206} \mathrm{~Pb} /{ }^{204} \mathrm{~Pb}$ component in Indian Ocean MORB has been present since the initial formation of the ocean, and, although minor in volume, it is widely distributed on each of the Indian Ocean ridge systems.

\section{Summary}

Eastern Indian Ocean seafloor basalts ranging in age from Eocene to late Jurassic are tholeiitic basalts, except at one site near Christmas Island where alkalic basalts were recovered. Both enriched and depleted MORB have been recovered. The isotopic characteristics of basalts younger than $125 \mathrm{Ma}$ indicate the presence of a Dupal component (lavas from Site 257 are an exception) that is absent in the oldest (155 Ma) seafloor samples. The first evidence of activity of the Kerguelen Plume is at 118 Ma with volcanism on the Kerguelen Plateau. This leads us to conclude that the Kerguelen Plume is the carrier of the Dupal anomaly in the Indian Ocean. In addition, we propose that the concentration of this anomaly in the southern bemisphere is related to the nearly fixed location of the African continent above the mantle. This situation favored recycling of continental lithosphere into the mantle via delamination. Delamination resulted either from thermal blanketing or underplating.

Some of the oldest seafloor lavas which predate volcanism associated with the Kerguelen Plume have the low ${ }^{206} \mathrm{~Pb} / 204 \mathrm{~Pb}$ values that are characteristic of some recent Indian Ocean MORB. Relatively low ${ }^{206} \mathrm{~Pb} /{ }^{204} \mathrm{~Pb}$ is typical of continental basalts in Madagascar and western Australia; therefore we infer that widely dispersed continental lithosphere is the source of the low ${ }^{206} \mathrm{~Pb} /{ }^{204} \mathrm{~Pb}$ in Indian Ocean MORB.

Relatively old, $>45 \mathrm{Ma}$, eastem Indian Ocean seafloor resulted from the activity of three different spreading systems which have been active at different time periods; in order of decreasing age these are a nearly east-west striking ridge in the Argo Abyssal plain bordering Northwest Australia, a northeast-southwest ridge bordering southwest Australia, and an east-west spreading system in the Wharton Basin (Figure 1). Basalts from the oldest spreading center, sampled at Sites 261 and 765 in the Argo Abyssal Plain, are depleted MORB that are very much like lavas erupted along the active Southeast Indian Ridge. In contrast basalts from the Wharton Basin, sampled at Sites 213, 212, and 256, have isotopic ratios indicating the presence of a Dupal component which was derived from the Kerguelen Plume.

Ackmowledgments. We thank J. M. Rhodes for use of the XRF facility at the University of Massachusetts, Amherst; P. Ila for assistance in data acquisition; J.-P. Mennessier for help with the isotope chemistry; J. Scoates for editorial assistance; and H.-J. Yang for graphics. We also thank J. Ryan, the JGR Associate Editor and an anonymous reviewer for constructive reviews, and we have benefited from discussions with $M$. Coffin and J. Veevers. This research was supported by U.S. NSF grants OCE-8823028 and EAR-9303535 and Belgian FRFC grant 2.9002.90.

\section{References}

Anderson, D.L., Isotopic evolution of the mantle: A model, Earth Planet. Sci. Lett., 57, 13-24, 1982.

Barling, J., S.L. Goldstein, and I.A. Nicholls, Geochemistry of Heard Island (southern Indian Ocean): Characterization of an enriched mantle component and implications for enrichment of the sub-Indian Ocean mantle, J. Petrol., 35, 1017-1053, 1994. 
Ben Othman, D., W.M. White, and J. Patchett, The geochemistry of marine sediments, island arc magma genesis, and crust-mantle recycling, Earth Planet. Sci. Lett., 94, 1-21, 1989.

Bienvenu, P., H. Bougault, M. Joron, and L. Dmitriev, MORB alteration: Rare-earth element/non-rare-earth hygromagmaphile element fractionation, Chem. Geol., 82, 1-14, 1990.

Cameron, A.E., D.H. Smith, and R.L. Walker, Mass spectrometry of nanogram-size samples of lead, Anal. Chem., 41, 525-526, 1969.

Castillo, P., The Dupal anomaly as a trace of the upwelling lower mantle, Nature, 336, 667-670, 1988.

Catanzaro, E.J., T.J. Murphy, W.R. Shields, and E.L. Garner, Absolute isotopic abundance ratios of common, equal-atom, and radiogenic lead isotope standards, J. Res. Natl. Bur. Stand., 72A, 261-267, 1968.

Davies, H.L., S.-S. Sun, F.A. Frey, I. Gautier, M.T. McCulloch, R.C. Price, Y. Bassias, C.T. Klootwijk, and L. Leclaire, Basalt basement from the Kerguelen Plateau and the trail of a Dupal plume, Contrib. Mineral. Petrol., 103, 457-469, 1989.

Davies, T.A., et al., Initial Reports of the Deep Sea Drilling Project, vol. 26, pp. 295-325, Washington, U.S. Govt. Print. Off., 1974.

Dosso, L., H. Bougault, P. Beuzart, J.Y. Calvez, and J.L. Joron, The geochemical structure of the South-East Indian ridge, Earth Planet. Sci. Lett., 88, 47-59, 1988.

Duncan, R.A., The age distribution of volcanism along aseismic ridges in the eastern Indian Ocean, Proc. Ocean Drill. Program Sci. Results,121, 507-517, 1991.

Dupré, B., and C.J. Allègre, $\mathrm{Pb}-\mathrm{Sr}$ isotope variation in Indian Ocean and mixing phenomena, Nature, 303, 142-146, 1983.

Falloon, T.J., R. Varne, J.D. Morris, and S.R. Hart, Alkaline volcanics from Christmas Island and nearby seamounts: Magmatism of the northeast Indian Ocean (abstract), in IAVCEI Meeting on Continental Magmatism, Bull. N. M. Bur. Mines Miner. Resour., 131, 86, 1989.

Fleet, A.J., P. Henderson, and D.R.C. Kempe, Rare earth element and related chemistry of some drilled southern Indian Ocean basalts and volcanogenic sediments, J. Geophys. Res., 81, 4257-4268, 1976.

Frey, F.A., and D. Weis, Geochemical constraints on the origin and evolution of the Ninetyeast Ridge: A $5000 \mathrm{~km}$ hotspot trace in the eastern Indian Ocean, Contrib. Mineral. Petrol., 121, 18-28, 1995.

Frey, F.A., J.S.J. Dickey, G. Thompson, and W.B. Bryan, Eastern Indian Ocean DSDP sites: Correlations between petrography, geochemistry and tectonic setting, in Synthesis of Deep Sea Drilling in the Indian Ocean, edited by J.R. Heirtzler and J.G. Sclater, pp. 189-257, U.S. Govt. Print. Off., Washington, D.C., 1977.

Frey, F.A., W.B. Jones, H. Davies, and D. Weis, Geochemical and petrologic data for basalts from Sites 756, 757, and 758: implications for the origin and evolution of Ninetyeast Ridge, in Proc. Ocean Drill. Program Sci. Results, 121, 611-659, 1991.

Frey, F.A., N.J. McNaughton, D.R. Nelson, J.R. deLaeter, and R. Duncan, Geochemical characteristics of the Bunbury Basalts, western Australia: Interaction between the Kerguelen Plume and Gondwana lithosphere, Earth Planet. Sci. Lett., in press, 1996.

Fullerton, L.G., W.W. Sager, and D.W. Handschumacker, Late Jurassicearly Cretaceous evolution of the eastern Indian Ocean adjacent to northwest Australia, J. Geophys. Res., 94, 2937-2953, 1989.

Gautier, I., D. Weis, J.-P. Mennessier, P. Vidal, A. Giret, and M. Loubet, Petrology and geochemistry of Kerguelen basalts (South Indian Ocean): Evolution of the mantle sources from ridge to an intraplate position, Earth Planet. Sci. Lett., 100, 59-76, 1990.

Hamelin, B., B. Dupré, and C.J. Allègre, Pb-Sr-Nd isotopic data of Indian Ocean ridges: New evidence of large-scale mapping of mantle heterogeneities, Earth Planet. Sci. Lett., 76, 288-298, 1985/1986.

Hart, S.R., The Dupal anomaly: A large scale isotopic mantle anomaly in the southern hemisphere, Nature, 309, 753-757, 1984.

Hart, S.R., Heterogeneous mantle domains: Signatures, genesis and mixing chronologies, Earth Planet. Sci. Lett., 90, 273-296, 1988.

Hart, S.R., D.C. Gerlach, and W.M. White, A possible new Sr-Nd-Pb mantle array and consequences for mantle mixing, Geochim. Cosmochim Acta, 50, 1551-1557, 1986.

Hart, S.R., E.H. Hauri, L.A. Oschmann, and J.A. Whitehead, Mantle plumes and entrainment: Isotopic evidence, Science, 256, 517-520, 1992.
Hawkesworth, C.J., M.S.M. Mantovani, P.N. Taylor, and Z. Palacz, Evidence from the Parana of south Brazil for a continental contribution to Dupal basalts, Nature, 322, 356-359, 1986.

Hekinian, R., Petrology of the Ninety East Ridge (Indian Ocean) compared to other aseismic ridges, Contrib. Mineral. Petrol., 43, 125$147,1974$.

Hickey-Vargas, R., J.M. Hergt, and P. Spadea, The Indian Ocean-type isotopic signature in Western Pacific marginal basins: Origin and significance, in Active Margins and Marginal Basins of the Westem Pacific, Geophys. Monogr. Ser., vol. 88, edited by B. Taylor and J. Natland, pp. 175-197, AGU, Washington, D.C., 1995.

Hofmann, A.W., Chemical differentiation of the Earth: The relationship between mantle, continental crust and oceanic crust, Earth Planet. Sci. Lett., 90, 297-314, 1988.

Hofmann, A.W., K.P. Jochum, M. Seufert and W.M. White, $\mathrm{Nb}$ and $\mathrm{Pb}$ in oceanic basalts: New constraints on mantle evolution, Earth Planet. Sci. Lett., 79, 33-45, 1986.

Ishiwatari, A., Petrology, geochemistry and mineralogy of the Early Cretaceous evolved N-MORB from Sites 765 and 766 eastern Indian Ocean, Proc. Ocean Drill. Program Sci. Results, 123, 209-213, 1992.

Ito, E., W.M. White, and C. Goepel, The O, Sr, Nd and $\mathrm{Pb}$ isotope geochemistry of MORB, Chem. Geol., 62, 157-176, 1987.

Leclaire, L., Y. Bassias, M. Denis-Clocchiatti, H. Davies, I. Gautier, and J. Wannesson, Lower Cretaceous basalt and sediment from the Kerguelen Plateau, Geo Mar. Lett., 7, 169-176, 1987.

Le Roex, A.P., H.J.B. Dick, A.J. Erlank, A.M. Reid, F.A. Frey, and S.R. Hart, Geochemistry, mineralogy and petrogenesis of lavas erupted along the southwest Indian Ridge between the Bouvet Triple Junction and $11^{\circ}$ east, J. Petrol., 24, 267-318, 1983.

Ludden, J.N., and B. Dionne, The geochemistry of oceanic crust at the onset of rifting in the Indian Ocean, Proc. Ocean Drill. Program Sci. Results 123, 791-799, 1992.

Luyendyk, B.P., and T.A. Davies, Results of DSDP Leg 26 and the geologic history of the Southern Indian Ocean, Initial Rep. Deep Sea Drill. Proj., 26, 909-943, 1974.

Mahoney, J.J., An isotopic study of Pacific oceanic plateaus: implications for their nature and origin, in Seamounts, lslands, and Atolls, Geophys. Monogr. Ser., vol. 43, edited by B.H. Keating, P. Fryer, R. Batiza, G.W. Boehlert, pp. 207-220, AGU, Washington, D. C., 1987.

Mahoney, J.J., and K.J. Spencer, Isotopic evidence for the origin of the Manihiki and Ontong Java oceanic plateaus, Earth Planet. Sci. Lett., 104, 196-210, 1991.

Mahoney, J.J., J.D. McDougall, G.W. Lugmair, and K. Gopalan, Kerguelen hot spot source for the Rajmahal traps and Ninetyeast Ridge, Nature, 303, 385-389, 1983.

Mahoney, J.J., J.H. Natland, W.M. White, R. Poreda, S.H. Bloomer, R.L. Fisher, and A.N. Baxter, Isotopic and geochemical provinces of the western Indian Ocean spreading centers, J. Geophys. Res., 94, 4033-4052, 1989.

Mahoney, J.J., A.P. Le Roex, Z. Peng, R.L. Fisher, and J.H. Natland, Sguthwestern limits of Indian Ocean ridge mantle and the origin of low $206 \mathrm{~Pb} /{ }^{204} \mathrm{~Pb}$ mid-ocean ridge basalt: Isotope systematics of the central Southwest Indian Ridge $\left(17^{\circ}-50^{\circ} \mathrm{E}\right), J$. Geophys. Res., $97,19,771$ 19,790, 1992.

Mahoney, J.J., W.B. Jones, F.A. Frey, V.J.M. Salters, D.G. Pyle, and H.L. Davies, Geochemical characteristics of lavas from Broken Ridge, the Naturaliste Plateau and southernmost Kerguelen plateau: Cretaceous Plateau Volcanism in the Southeast Indian Ocean, Chem. Geol., 120, 315-345, 1995.

Manhès, G., J.-P. Minster, and C.J. Allègre, Comparative uraniumthorium-lead and rubidium-strontium of St. Severin amphoterite: Consequences for early solar system chronology, Earth Planet. Sci. Lett., 39, 14-24, 1978.

Markl, R.G., Evidence for the breakup of eastern Gondwanaland by the early Cretaceous, Nature, 251, 196-200, 1974.

McDougall, I., Potassium-argon ages on basaltic rocks recovered from DSDP, Leg 22, Indian Ocean, Initial Rep. Deep Sea Drill. Proj., 22, 377-379, 1974.

Melson, W.G., T.L. Vallier, T.L. Wright, G. Byerly, and J. Nelen, Chemical diversity of abyssal volcanic glass erupted along Pacific, 
Atlantic and Indian Ocean seafloor spreading centers, in Geophysics of the Pacific Ocean Basin and Its Margin, Geophys. Monogr. Ser., vol. 19, edited by G.H. Sutton, M.H. Manghnani, and R. Moberly, pp. 351368, AGU, Washington, D. C., 1975.

Michard, A., R. Montigny, and R. Schlich, Geochemistry of the mantle below the Rodriquez Triple junction and the South-East Indian Ridge, Earth Planet. Sci. Lett., 78, 104-114, 1986.

Müller, R.D., J.V. Royer, and L.A. Lawver, Revised plate motions relative to hotspots from combined Atlantic and Indian Ocean hotspot tracks, Geology, 21, 275-278, 1993.

Powell, C.M., S.R. Roots, and J.J. Veevers, Pre-breakup continental extension in East Gondwanaland and the early opening of the eastern Indian Ocean, Tectonophysics, 155, 261-283, 1988.

Price, R.C., A.K. Kennedy, M. Riggs-Sneeringer, and F.A. Frey, Geochemistry of basalts from the Indian Ocean triple junction: Implications for the generation and evolution of Indian Ocean ridge basalts, Earth Planet. Sci. Lett., 78, 379-396, 1986.

Pringle, M.S, M. Storey, and J. Wijbrans, ${ }^{40} \mathrm{Ar} /{ }^{39} \mathrm{Ar}$ geochronology of mid-Cretaceous Indian Ocean basalts: Constraints on the origin of large flood basalt provinces, Eos, Trans. AGU, 75 (44), Fall. Meet. Suppl., 728, 1994.

Rhodes, J.M., C. Morgan, and R.A. Lilas, Geochemistry of Axial seamount lavas: magmatic relationship between the Cobb hotspot and the Juan de Fuca Ridge, J. Geophys. Res., 95, 12,713-12,733, 1990.

Robinson, P.T., and D.J. Whitford, Basalts from the eastern Indian Ocean, DSDP leg 27, Initial Rep. Deep Sea Drill. Proj.. 27, 551-559, 1974.

Royer, J.-Y., J.W. Peirce, and J.K. Weissel, Tectonic constraints on hotspot formation of the Ninetyeast Ridge, Proc. Ocean Drill. Program Sci. Results 121, 763-776, 1991.

Rundle, C.C., M. Brook, N.J. Snelling, P.H. Reynolds, and S.M. Barr, Radiometric age determinations, Initial Rep. Deep Sea Drill. Proj., 26, 513-516, 1974.

Salters, V.J.M., M. Storey, J.H. Sevigny, and H. Whitechurch, Trace element and isotopic characteristics of Kerguelen-Heard plateau basalts, Proc. Ocean Drill. Program Sci. Results 120, 55-62, 1991.

Saunders, A.D., M. Storey, I.L. Gibson, P. Leat, J. Hergt, and R.N. Thompson, Chemical and isotopic constraints on the origin of the basalts from the Ninetyeast Ridge, Indian Ocean: results from DSDP Legs 22 and 26 and ODP Leg 121, Proc. Ocean Drill. Program Sci. Results 121, 559-590, 1991.

Sclater, J.G., C. von der Borch, J.J. Veevers, R. Hekinian, R.W. Thompson, A.C. Pimm, B. McGowran, S.J. Gartner, and D.A. Johnson, Regional synthesis of the Deep Sea Drilling result from Leg 22 in the eastern Indian Ocean,Initial Rep. Deep Sea Drill. Proj. 22, 815-831, 1974.

Smith, N.C., and E.D. Mountain, The volcanic rocks of Christmas Island (Indjan Ocean), Q. J. Geol. Soc. London, 82, 44-66, 1925.

Staudigel, H., G.R. Davies, S.R. Hart, K.M. Marchant, and B.M. Smith, Large scale isotopic $\mathrm{Sr}, \mathrm{Nd}$ and $\mathrm{O}$ isotopic anatomy of altered oceanic crust: DSDP/ODP Sites 417/418, Earth Planet. Sci. Lett., 130, 169$185,1995$.

Storey, M., A.D. Saunders, J. Tarney, P. Leat, M.F. Thirlwall, R.N. Thompson, M.A. Menzies, and G.F. Marriner, Geochemical evidence for plume-mantle interactions beneath Kerguelen and Heard Islands, Indian Ocean, Nature, 336, 371-374, 1988.

Storey, M., A.D. Saunders, J. Tarney, I.L. Gibson, M.J. Norry, M.F. Thirwall, P. Leat, R.N. Thompson, and M.A. Menzies, Contamination of Indjan Ocean asthenosphere by the Kerguelen-Heard mantle plume, Nature, 338, 574-576, 1989.

Storey, M., R. Kent, A.D. Saunders, V.J. Salters, J. Hergt, H. Whitechurch, J.H. Sevigny, M.F. Thirwall, P. Leat, N.C. Ghose, and M. Gifford, Lower Cretaceous volcanic rocks along continental margins and their relationship to the Kerguelen Plateau, Proc. Ocean Drill. Program Sci. Results 120, 33-53, 1992.

Subbarao, K.V., and C.E. Hedge, $\mathrm{K}, \mathrm{Rb}, \mathrm{Sr}$ and ${ }^{87} \mathrm{Sr} /{ }^{86} \mathrm{Sr}$ in rocks from the Mid-Indian Ocean ridge, Earth Planet. Sci. Lett., 18, 223-228, 1973.
Sun, S.-S., and W.F. McDonough, Chemical and isotopic systematics of oceanic basalts: implications for mantle composition and processes, in Magmatism in the Ocean Basins, edited by A.D. Saunders and M.J. Norry, pp. 313-345, Blackwell Sci., Cambridge, Mass., 1989.

Veevers, J.J., et al., Initial Reports of the Deep Sea Drilling Project, vol. 27, 1060 pp., U.S. Govt. Print. Off., Washington, D. C., 1974.

von der Borch, C.C., et al., Initial Reports of the Deep Sea Drilling Project, vol. 22, 890 pp., U.S. Govt. Print. Off., Washington, D. C., 1974.

Vroon, P.Z., M.J. van Bergen, W.M. White, and J.C. Varekamp, Sr-Nd$\mathrm{Pb}$ isotope systematics of the Banda Arc, Indonesia: Combined subduction and assimilation of continental material, J. Geophys. Res., 98, 22,349-22,366, 1993.

Weaver, B.L., The origin of oceanic island basalt end-member compositions: Trace element and isotopic constraints, Earth Planet. Sci. Lett., 104, 381-397, 1991.

Weis, D., Role of the Kerguelen Plume in the geochemical evolution of the Indian Ocean, Habilitation thesis thesis, Univ. Libre de Bruxelles, Brussels, Belgium, 1992.

Weis, D., and F.A. Frey, Isotope geochemistry of Ninetyeast Ridge basalts: $\mathrm{Sr}, \mathrm{Nd}$, and $\mathrm{Pb}$ evidence for the involvement of the Kerguelen hot spot, Proc. Ocean Drill. Program Sci. Results 121, 591-610, 1991.

Weis, D., D. Demaiffe, S. Cauët, and M. Javoy, $\mathrm{Sr}, \mathrm{Nd}, \mathrm{O}$ and $\mathrm{H}$ isotopic ratios in Ascension Island lavas and plutonic inclusions: Cogenetic origin, Earth Planet. Sci. Lett., 82, 255-268, 1987.

Weis, D., Y. Bassias, I. Gautier, and J.-P. Mennessier, Dupal anornaly in existence $115 \mathrm{Ma}$ ago: evidence from isotopic study of the Kerguelen Plateau (South Indian Ocean), Geochim Cosmochim. Acta, 53, 21252131, 1989a.

Weis, D., J.-F. Beaux, I. Gautier, A. Giret, and P. Vidal, Kerguelen Archipelago: Geochemical evidence for recycled material, in Crust/Mantle Recycling at Convergence Zones, edited by S.R. Hart, and L. Gülen, pp. 59-63, Kluwer Acad., Norwell, Mass., 1989b.

Weis, D., W.M. White, F.A. Frey, R.A. Duncan, J. Dehn, M. Fisk, J. Ludden, A. Saunders, and M. Storey, The influence of mantle plumes in generation of Indian Oceanic crust, in Synthesis of results from the Scientific Drilling in the Indian Ocean, Geophys. Monogr. Ser., vol. 70, ed. by R.A. Duncan et al., pp. 57-89, AGU, Washington, D. C., 1992.

Weis, D., F.A. Frey, H. Leyrit, and I. Gautier, Kerguelen Archipelago revisited: geochernical and isotopic study of the SE Province lavas, Earth Planet. Sci. Lett., 118, 101-119, 1993a.

Weis, D., A. Giret, and F.A. Frey, Evolution of the Kerguelen Plume with time: Geochemical evidence from the Ross volcano, Eos, Trans. AGU, 74 (43), Fall. Meet. Suppl., 632, 1993 b.

White, R., and D.P. McKenzie, Magmatism at rift zones: the generation of volcanic continental margins and flood basalts, J. Geophys. Res., 94, 7685-7729, 1989.

White, W.M., ${ }^{238} \mathrm{U} /{ }^{204} \mathrm{~Pb}$ in MORB and open system evolution of the depleted mantle, Earth Planet. Sci. Lett., 115, 211-226, 1993.

Whitechurch, H., R. Montigny, J. Sevigny, M. Storey, and V. Salters, ${ }^{40} \mathrm{Ar} /{ }^{39} \mathrm{Ar}$ ages of central Kerguelen Plateau basalts, Proc. Ocean Drill. Program Sci. Results, 120, 71-78, 1992.

Zindler, A., and S.R. Hart, Chemical geodynamics, Annu. Rev. Earth Planet. Sci., 14, 493-571, 1986.

F. A. Frey, 54-1226, Department of Earth, Atmospheric and Planetary Sciences, Massachusetts Institute of Technology, Cambridge, MA 021394307. (e-mail: fafrey@ mit.edu)

D. Weis, Mâtre de Recherches FNRS, Département des Sciences de la Terre et de l'Environnement, CP 160/02, Université Libre de Bruxelles, Avenue F.D. Roosevelt, 50, B-1050 Brussels, Belgium. (e-mail: dweis@resulb.ulb.ac.be)

(Received March 1, 1995; revised January 22, 1996; accepted January 31, 1996.) 